\title{
On the CIAM 7 Grid: From an Ideological to a Critical Tool
}

\author{
Pierre-Alain Croset, Andrea Canclini
}

THEORY

\begin{abstract}
Much historiographical research has been produced on the post-war CIAMs, demonstrating the importance of the CIAM Grid, proposed as a "thinking tool" for representing the town planning projects at the CIAM 7 in Bergamo (1949). This essay proposes a new critical and epistemological examination of the CIAM Grid based on new archival documents and on a rereading of the exact words used by Le Corbusier, who proposed to consider the Grid as an "interlocutor." Seventy years later, we propose to go beyond the failure of CIAM 7 and to elaborate a "new Grid," with the name of "Second Life Grid," as a critical tool for discussing exclusively projects related to the new paradigm of recycling and reusing buildings and urban spaces. Beginning with the question of the critical legacy of the CIAM Grid, our intention was to think of a Grid conceived no longer as an instrument of dogmatic and normative thought, but as an instrument of dialogical criticism which has been tested through an open call for projects and an international conference held in Bergamo in October, 2019.
\end{abstract}

Keywords: Athens Charter, Bergamo, CIAM Grid, Le Corbusier, Second Life Grid

Bergamo's CIAM 7 (July 24-30, 1949) is often remembered as "the 'grid' congress." " After seventy years, much historiographical research has been produced on post-war CIAMs leading to the conclusion that CIAM 7, more than any other post-war congress, was "a failure." ${ }^{2}$ In particular, the research produced by Eric Mumford ${ }^{3}$ and by Annie Pedret ${ }^{4}$ not only demonstrated the profound contradictions between the intentions and the 
results but also between the conclusions expressed in the official reports and the contents of the debates that took place in Bergamo. ${ }^{5}$

The facts regarding the preparation of CIAM 7 are well known. At CIAM 6 in Bridgwater (September 7-14,1947), the first post-war congress after a 10-year interruption, the organization of the subsequent congress was discussed in a commission led by Le Corbusier, which included several members of the French group (ASCORAL) and the English group (MARS). It was decided that in order to favor "a concise comparative analysis of the various problems in each country" a "standard method of graphic presentation for this purpose" 6 should be developed. Subsequently, ASCORAL took charge not only of the "CIAM Grid" as a unified framework for the presentation ${ }^{7}$ of urban planning projects "in application of the Athens Charter," but also of the CIAM 7 final program organization. After several months of elaboration, ${ }^{8}$ this Grid was approved in March 1948 by the CIAM Council, and subsequently published in a booklet, printed in French and English by L'Architecture d'Aujourd'hui, ${ }^{9}$ and sent to all CIAM members as an official invitation to a "Working Congress" whose venue and dates had not yet been determined. ${ }^{10}$ (Fig. 1.)

Despite the fact that the CIAM grid was widely criticized and subsequently abandoned, this essay, structured in three parts, aims at exploring the Grid beyond its failure from a new critical and epistemological perspective. The essay's first section presents original archival documents that allow a better understanding of the relationship between the overall failure of CIAM 7 on the one hand, and the specific failure of the Grid as an ideological tool on the other. The second section suggests a new interpretation of a specific terminology used by Le Corbusier in reference to the Grid. The last part proposes the development of the "Second Life Grid," which overcomes the CIAM 7 failure; it is a new Grid, conceived as a critical tool to exclusively discuss projects related to the paradigm of transformation, that of recycling and reusing buildings and urban spaces.

\section{THREE REASONS FOR THE FAILURE OF THE CIAM GRID}

Through a comparison between the ambitious program expressed in the pre-published booklet and the results of CIAM 7, this section provides a thorough examination of the deep contradictions that led to three different orders of failure. Firstly, the number of urban projects exhibited in Bergamo was lower than expected. ${ }^{11}$ With a marked absence not only from countries represented with official delegates such as the United States, Algeria, Belgium, Denmark, Czechoslovakia, Uruguay, Japan, Norway, and Poland, but also from other countries not yet officially in the CIAM, but who had been invited to participate with town planning projects in order to confirm the desired enlargement of the CIAM as an international group. ${ }^{12}$ These countries include the USSR, Turkey, Finland, Hungary, Yugoslavia, Palestine, Tunisia, Australia, and Mexico. It is quite difficult to specify the 
(a)

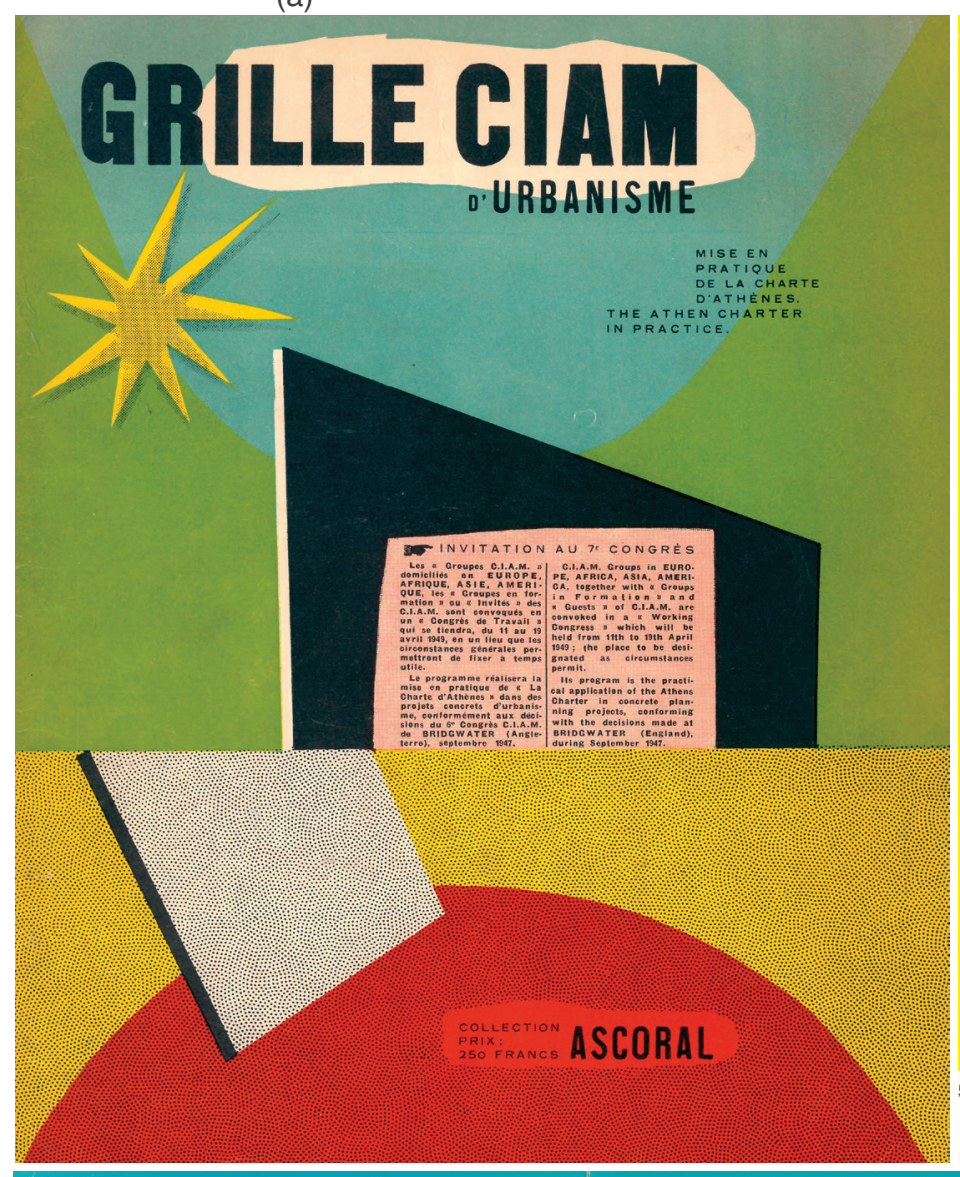

(b)

\begin{tabular}{|c|c|c|c|c|c|c|c|}
\hline \multirow{2}{*}{ 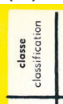 } & \multirow{2}{*}{\multicolumn{2}{|c|}{ 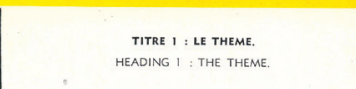 }} & \multicolumn{4}{|c|}{$\begin{array}{lllllll}\text { LES } & \text { F OON } & N & C & T \\
T\end{array}$} & \multirow[b]{2}{*}{ d. divent: } \\
\hline & & & & & 3 & 4 & \\
\hline \multirow{2}{*}{10} & 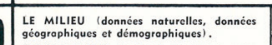 & 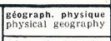 & & & pis & & \\
\hline & 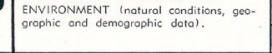 & 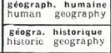 & & & & & \\
\hline \multirow{3}{*}{11} & \multirow{3}{*}{ 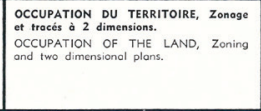 } & 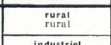 & & & & ${ }^{n+1+4}$ & \\
\hline & & 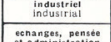 & & & & & \\
\hline & & 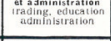 & 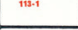 & & & & \\
\hline \multirow[t]{2}{*}{12} & \multirow{2}{*}{ 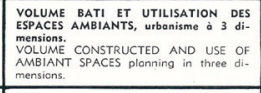 } & 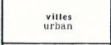 & & mis & & & \\
\hline & & 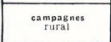 & & $\min$ & & & \\
\hline 13 & 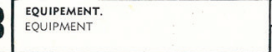 & 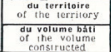 & & $n_{n+2}$ & & & \\
\hline 14 & \multicolumn{2}{|c|}{ 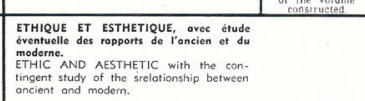 } & & $n=2$ & nas & & \\
\hline 15 & \multicolumn{2}{|l|}{ 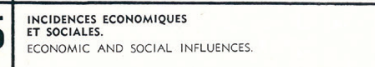 } & & $m=2$ & & & \\
\hline 16 & \multicolumn{2}{|l|}{ 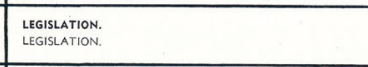 } & & & 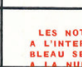 & 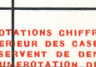 & 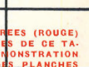 \\
\hline 17 & \multicolumn{2}{|l|}{\begin{tabular}{|l}
$\begin{array}{l}\text { FINAACENENT. } \\
\text { FNNANE. }\end{array}$ \\
\end{tabular}} & & & 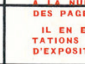 & 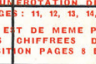 & 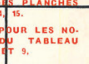 \\
\hline 18 & \multicolumn{2}{|l|}{ 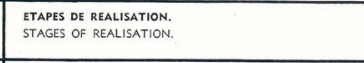 } & & & & & \\
\hline 19 & \multicolumn{2}{|l|}{ 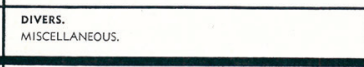 } & & & & & \\
\hline \multirow{2}{*}{ 章 } & \multirow{2}{*}{\multicolumn{2}{|c|}{ 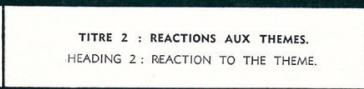 }} & & 4 & & 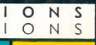 & \\
\hline & & & & & 3 & 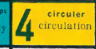 & d. \\
\hline 20 & 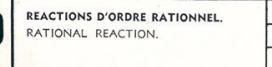 & 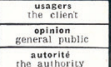 & & & & & \\
\hline & 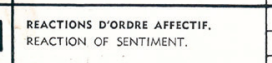 & 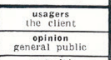 & & & & & - \\
\hline & A & & & & & & \\
\hline
\end{tabular}

(c)
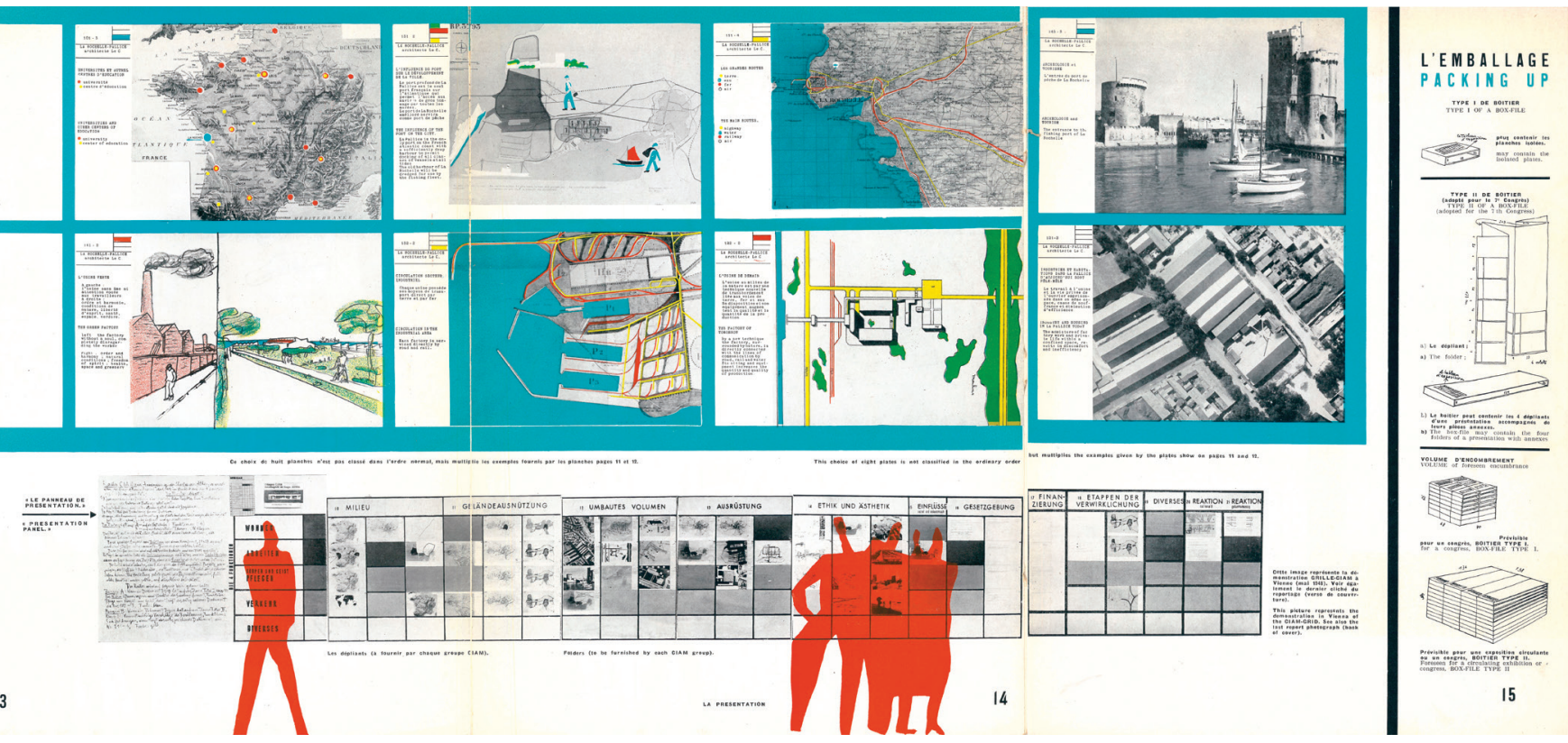

Figure 1. Grille CIAM, studied by the French group of CIAM (ASCORAL): (a) cover of the booklet (1948) with the invitation to the CIAM 7; (b) the grid as presented in the booklet of 1948, with columns related to the 4 functions of the Athens Charter, and rows (10-19) which represent ten themes according to which it is possible to consider a project, with the addition of two more (20-21) that represent the "rational" or "subjective" reactions of users to a project (the Grid used at Bergamo for the exhibition of projects had rows and columns inverted); (c) the pages 13-15 of the booklet with an example of a complete Grid, as presented in May 1948 in Vienna as a demonstration. 
exact number of projects actually exhibited and discussed in Bergamo due to conflicting data emerging from archival documents. At the congress opening on July 24, 1949, Le Corbusier presented the extensive work-in-progress on the Grid as a success, given that twenty-eight grids had arrived in Bergamo. ${ }^{13}$ However, based on the ETH Zurich's CIAM Archive, Eric Mumford enlists thirty projects, ${ }^{14}$ while other documents in Nino Zucchelli's Archive, preserved at the Galleria d'Arte Moderna e Contemporanea (GAMEC) of Bergamo, ${ }^{15}$ indicate that at least four other projects were exhibited in Bergamo. ${ }^{16}$ The displayed projects could, therefore, have been thirty-four instead of twenty-eight even if the layout drawings designed by Franco Albini and Nestorio Sacchi ${ }^{17}$ (Fig. 2) show an arrangement of fourteen long wooden panels (dimensions 1,36 x 9,62 m - 55 in. $x 3 \mathrm{ft} .6$ in.) hanging by tie-rods from the chains of the great trusses of the historic Palazzo della Ragione in Bergamo, which effectively allowed twenty-eight grids to be exhibited..$^{18}$

Secondly, the organizers intended to use the CIAM Grid not only as a representation tool but also as a normative instrument binding the participants to the principles of functionalist town planning codified in the Athens Charter. ${ }^{19} \mathrm{CIAM} 7$ was meant to celebrate the triumph of functionalist town planning. In reality, it became the scene of violent disputes that led to antagonistic positions, ${ }^{20}$ in particular from the CIAM's Dutch and English groups. Contrary to the triumphalist tones of the Final Report stating that "an indisputable and impressive unity reigns through all these town plans," ${ }^{21}$ the CIAM Grid was heavily criticized for being "excessively rigid," and, therefore, for its very principles of functionalist urbanism that were challenged during the conference. ${ }^{22}$ Furthermore, not all participants respected the Grid's graphic format, as Le Corbusier had alluded to in his inaugural speech at the congress: "there were, as always, the few rebels who claim to do it differently." ${ }^{23}$ The event photographs of the great hall of the Palazzo della Ragione, showing the delegates sitting in the foreground and the Grids display in the background (Fig. 3), reveal that some projects were exhibited either without following the Grid's strict graphic guidelines or with visible gaps. ${ }^{24}$ The few photographs documenting the exhibition in Bergamo only show fragments of Grids, for example, in the beautiful photograph of Le Corbusier (Fig. 4) in front of the Grid of Buenos Aires' town plan (published in L'Illustrazione Italiana, July 31, 1949). It is, therefore, not possible to verify how the CIAM Grid had actually been used or interpreted to represent the various town plans. ${ }^{25}$

However, the criticism of the Grid was not only related to ideological or doctrinal issues, but also to evident difficulties of interpretation and application. Rereading the extensively detailed instructions contained in the 1948 publication today, it is possible to understand the reasons why the author of a town plan, not necessarily drawn up according to the principles of the Athens Charter, could be lost in the face of the obligation to choose the intersection box between the four functions (horizontally) and the twelve 
(a)

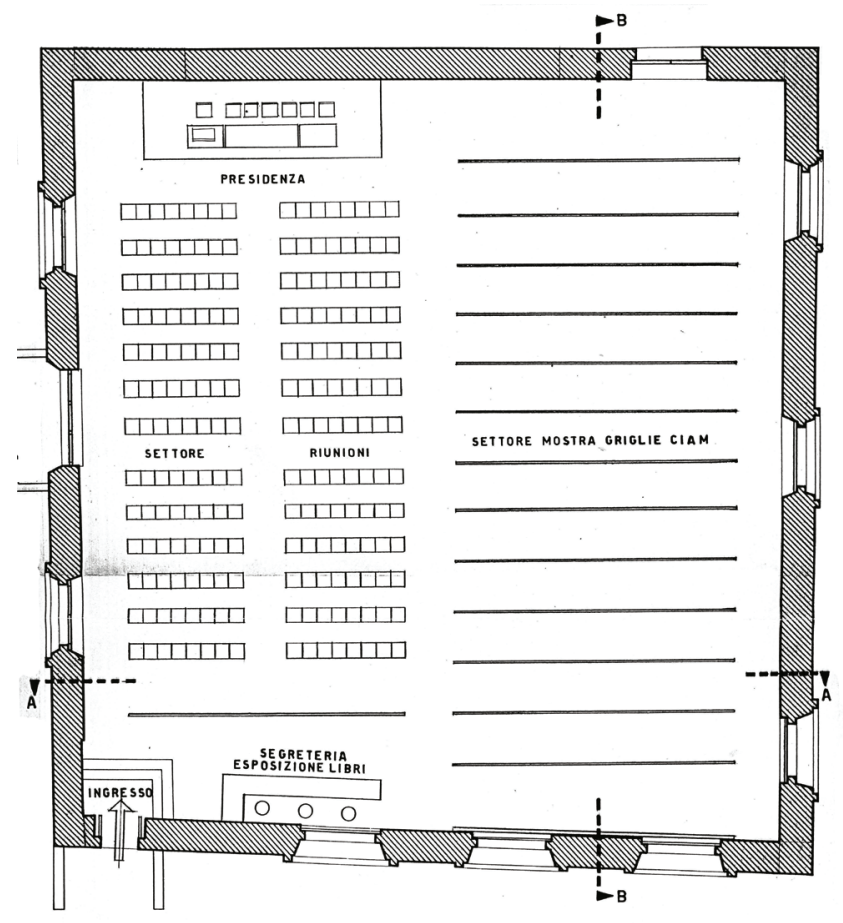

(b)

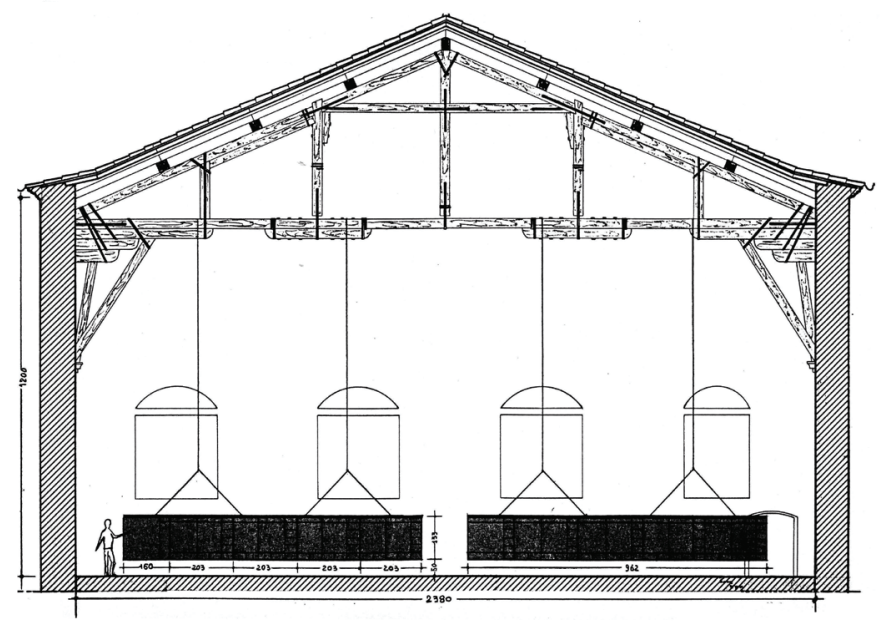

(c)

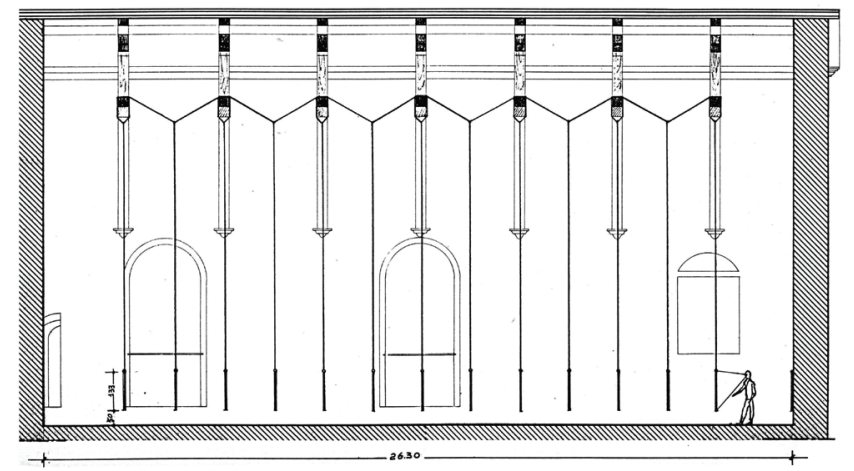

Figure 2. Layout for the CIAM exhibition and congress in the Palazzo della Ragione in Bergamo (project by Franco Albini and Nestorio Sacchi): the room was divided into two symmetrical parts, the first one with the seats, the second one with fourteen long wooden panels (dimensions 1,36 x 9,62 m- 4 ft. 6 in. x $31 \mathrm{ft} .6 \mathrm{in}$.), hanging by means of tie-rods from the chains of the great trusses of the historic roof - (a) plan; (b) cross-section; (c) longitudinal section. 
(a)

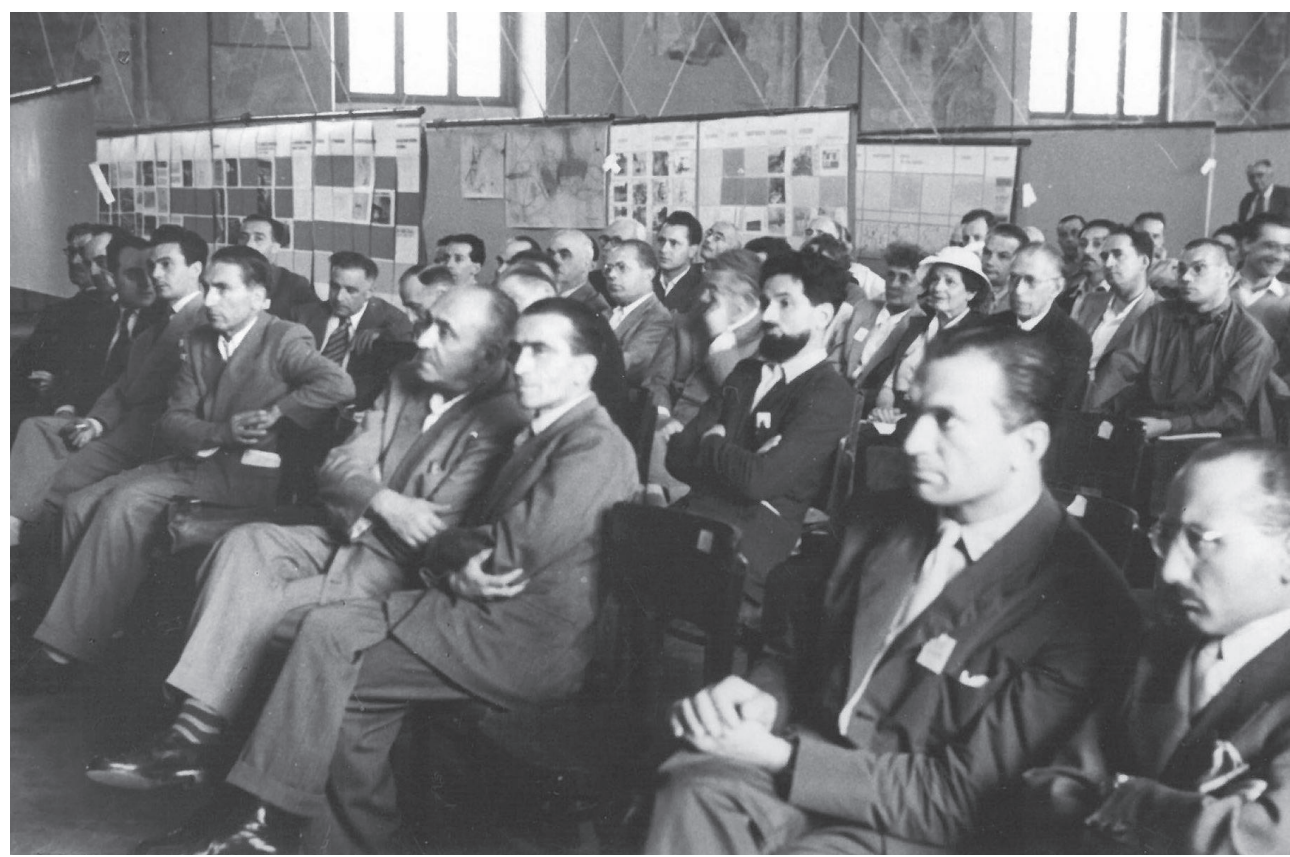

(b)

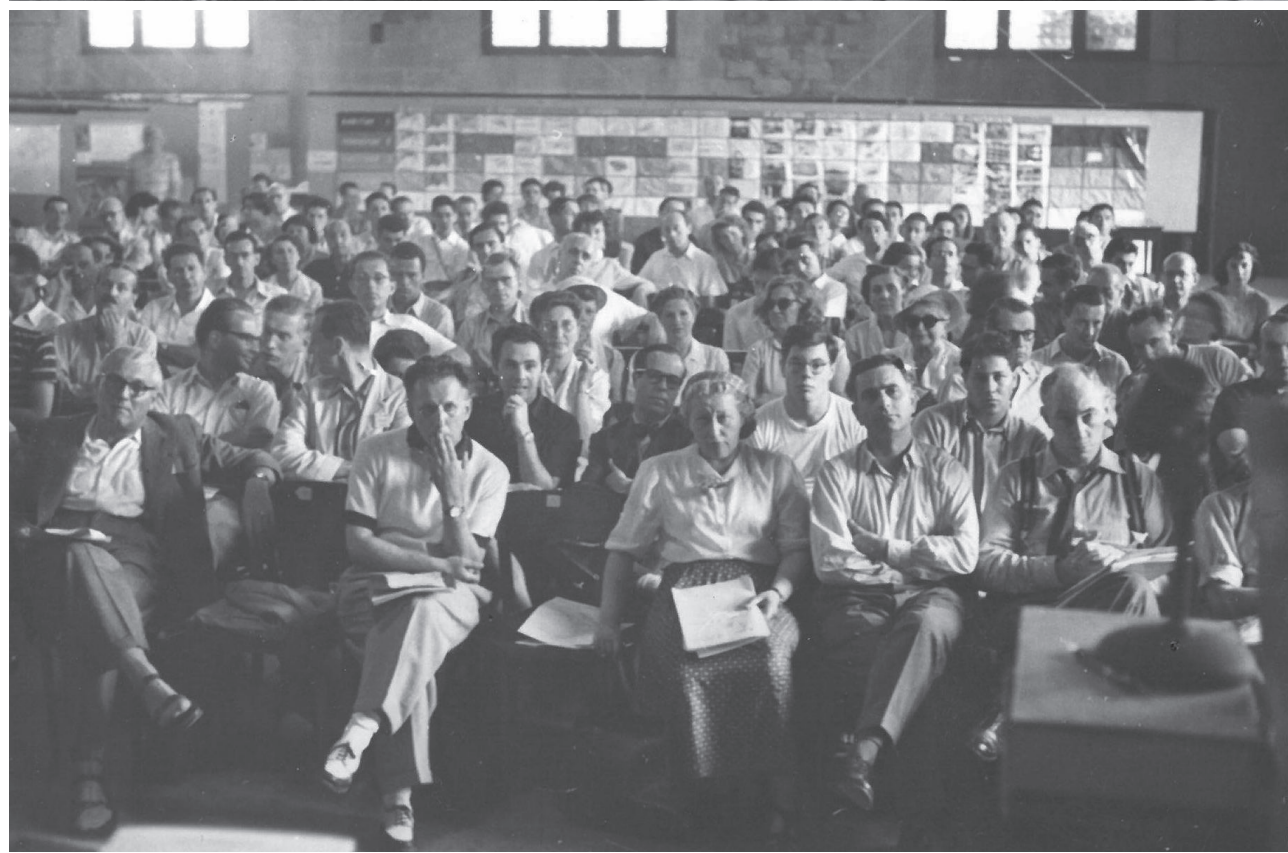

Figure 3. The space of Palazzo della Ragione during the CIAM 7 Congress: (a) behind the CIAM delegates, it is clearly visible that some projects were exhibited without respecting the graphic layout of the CIAM Grid, or with showy gaps; (b) the general assembly of the CIAM, with a complete grid at the rear.

themes (vertically), in order to insert drawings, photographs and texts. ${ }^{26}$ The booklet itself contained several errors in the plates' numbering, ${ }^{27}$ (Fig. 5) forcing a series of errata inserted as a bound postcard between pages 24 and 25 of the publication; this indicated how the CIAM grid authors themselves had difficulties using the instructions. Le Corbusier himself was aware of these problems to the point of stating in his opening speech, "Improve the Grid by all means, but do not smash it!" ${ }^{28}$ Originally 
(a)

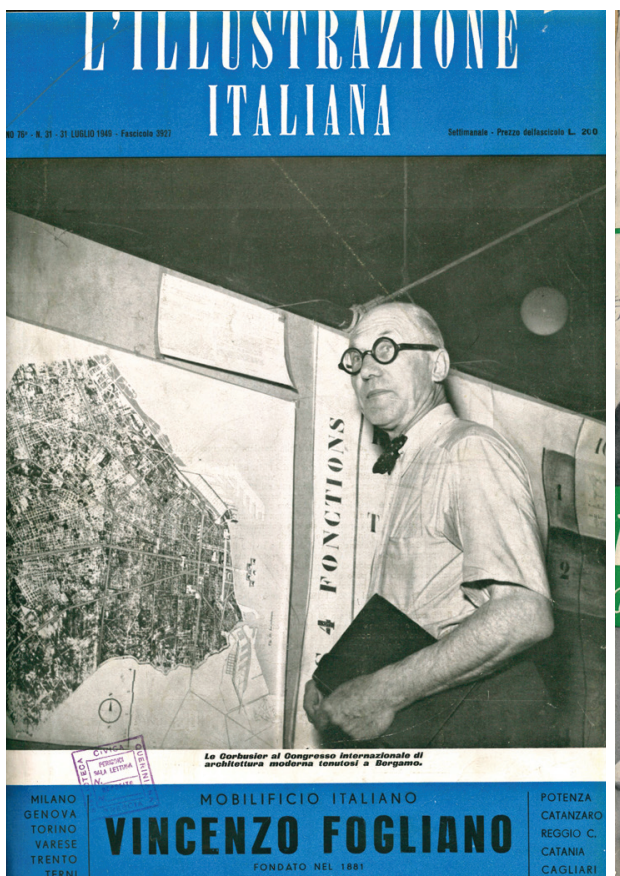

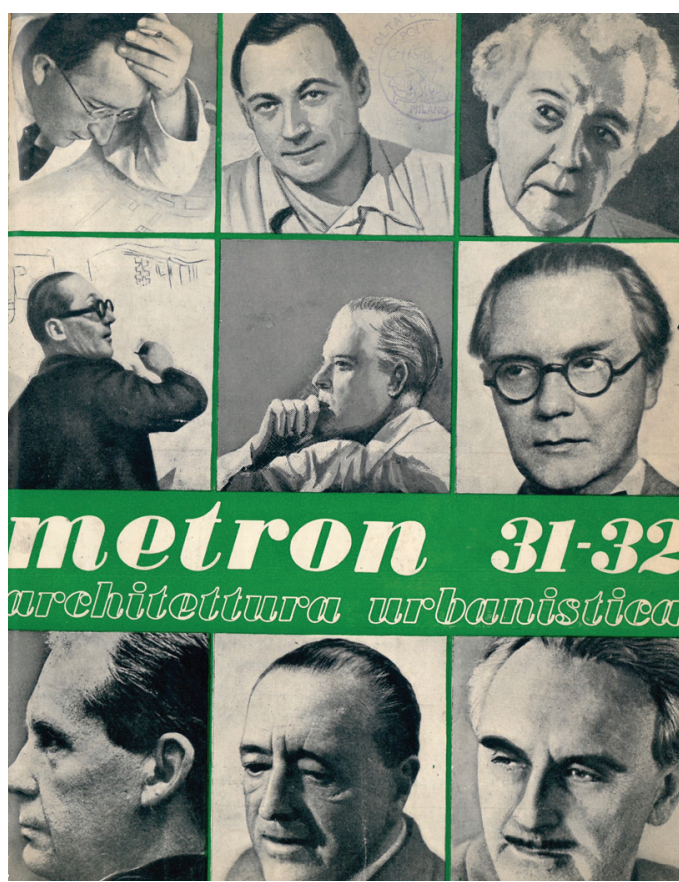

Figure 4. (a) Cover of the magazine L'Illustrazione Italiana (July 31, 1948), with Le Corbusier in front of the Grid of the town plan for Buenos-Aires (July 24, 1949); (b) cover of Metron 31-32 (1948), with the portraits of Mendelsohn, Aalto, Wright, Le Corbusier, Roth, Asplund, Gropius, Mies, Neutra, as an illustration of the essay "Concerning Architectural Culture: A Message to the Congrès International d'Architecture Moderne," in which Bruno Zevi proposed an extension of the CIAM to architects coming from "organic" trends of the modern movement.

set up to improve the Grid and prepare for the next congress, SubCommission 1B (President Cornelis van Eesteren), became a veritable stage of accusations, expressing radical criticisms and proposing the complete elimination of the horizontal divisions, ${ }^{29}$ which were rather considered "absolutely necessary to preserve" by Le Corbusier. ${ }^{30}$ However, the principle of using a grid to display a collection of projects was not abandoned. Instead, it was profoundly reformed in the subsequent CIAM 8 of Hoddesdon (1951) dedicated to the theme "The Heart of the City," for which the organizing group prepared a new grid entitled "MARS Grid." ${ }^{11}$ (Fig. 6.) Very simplified, this grid included only six columns corresponding to four horizontal fields. Unlike the CIAM Grid, the horizontal rows did not correspond to functions or themes but rather were inflected by the subject indicated in the title of each column. ${ }^{32}$ This allowed for greater simplicity and flexibility, where the MARS Grid functioned as a descriptive non-interpretative grid.

Thirdly, the CIAM Grid was conceived as a detailed and sophisticated tool not only to exhibit projects in Bergamo at the time but also to guarantee a wide distribution of projects through future publications. Through previous conferences, the CIAM Congresses had already dedicated great importance to the dissemination of results and the promotion of principles 


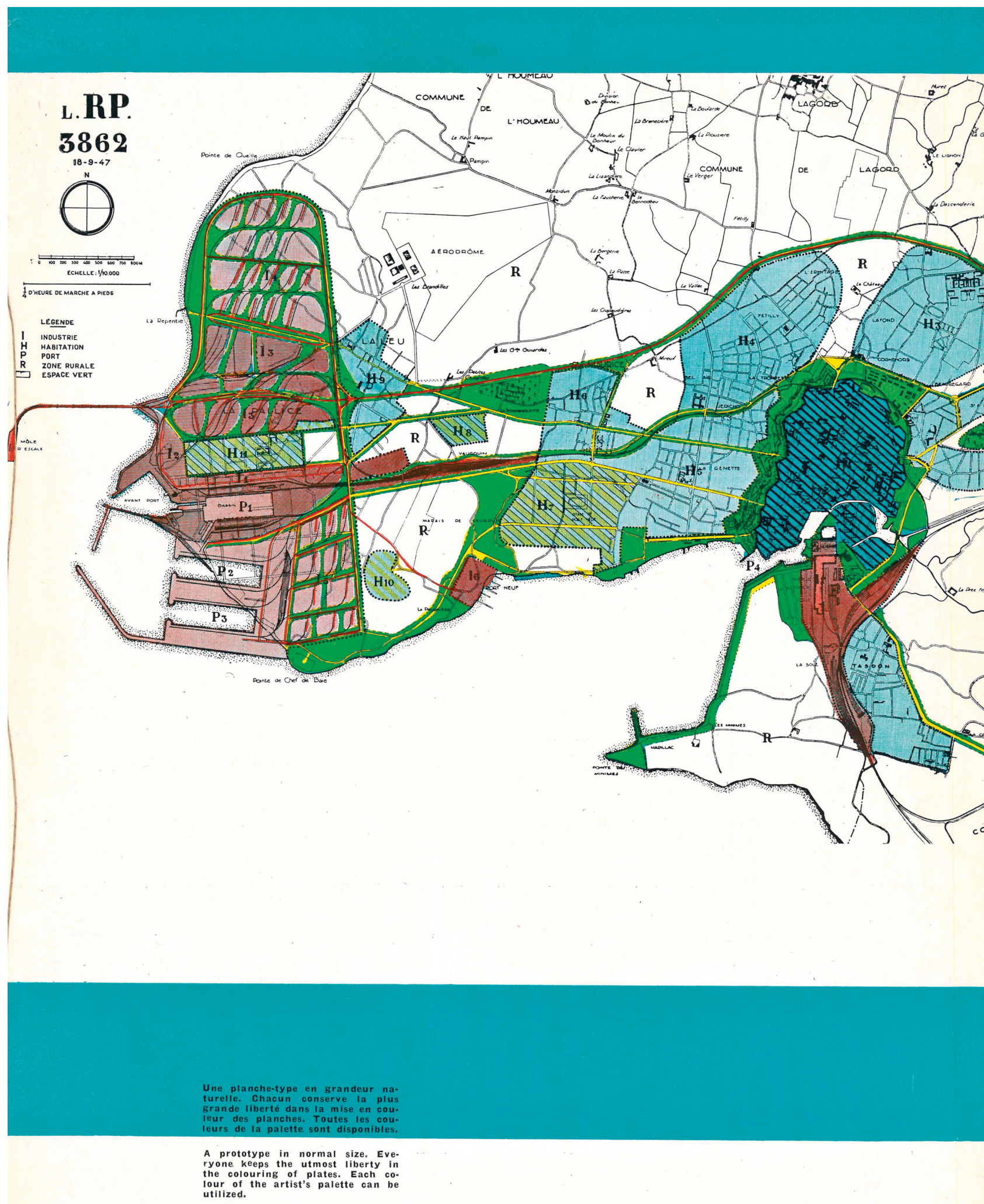

Figure 5. Pages 11-12 of the booklet on the CIAM Grid (1948), with an example of a board $\left(21 \times 33 \mathrm{~cm} ; 81 \frac{1}{4} \times 13 \mathrm{in}\right.$.) and the explanations for the captions. Each board had to be marked at the top right with a reference number that referred to the main theme and function, while a second colored mark, organized on four lines, making it possible to highlight the possible mix between different functions of the Athens Charter. 

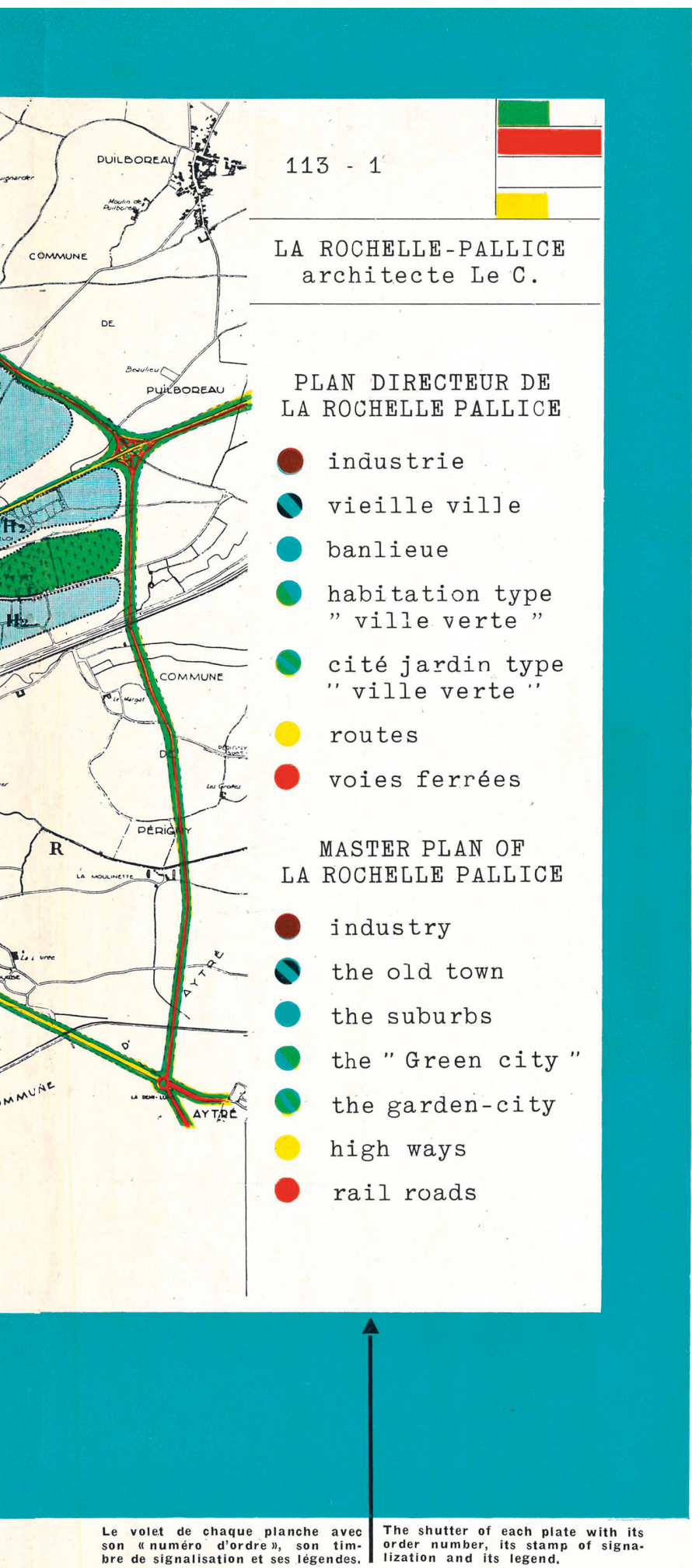

Le boîtier recevant le dépliant sera de $34 \mathrm{~cm} . \times 134$ $\mathrm{cm}$., mesures intérieures.

Le BOITIER sera muni d'un exemplaire du Tableau d'Exposition collé sur une de ses faces.

Les "Annexes " seront également coupées et collées sur toile à la largeur standard de $33 \mathrm{~cm}$. et seront logées dans un second boîtier.

Les envois devront parvenir au :

SECRETARIAT GENERAL DES C.I.A.M

Doldertal, 7 - Zurich, 7 (Suisse)

Pour réaliser les planches de la PRESENTATION, on se servira à volonté de réductions photographiques au format $21 \times 27$, ou de textes. Ces photographies reproduiront des documents géographiques, topographiques, etc..., paysagistes, monuments historiques, vues d'avion, graphiques, etc..., des plans d'urbanisme (ensembles ou fragments), des plans d'architecture, de génie civil, etc... La même réduction photographique pourra être employée dans plusieurs cases; mais des traits ou taches de couleurs préciseront ici des questions de circulation, là de zonage, etc...

La mélhode technique la plus favorable consiste certainement à réduire photographiquement la totalité des planches. Cette méthode apportera de l'unité à la présentation. Les adjonctions de couleurs devraient se faire aux encres indélébiles. Si l'on employait de la gouache, il faudrait recourir à un moyen de fixation de la couleur par un vernis transparent.

Les inscriptions essentielles (suir les planches) seront en francais et en anglais.

La PRESENTATION permettra une lecture instantanée d'un projef d'urbanisme, par fonctions, ou par classes, se prêtant ainsi à toutes les analyses et a tous les commentaires (opinion publique, autorités, spécialistes, sociologues, économistes, techniciens, etc...)

The “Appendices » should be mounted similarly on linen folders of a standard width of $33 \mathrm{~cm}$. and housed in a second boxfile.

The Material should be dispatched so as to arrive by March 1st 1949 at the :

SECRETARIAT GENERAL DES C.I.A.M.

Doldertal No 7, Zurich (7), Switzerland

The plates comprising the PRESENTATION may be in the form of photostatic reduction or of texts $(21 \times 27 \mathrm{~cm}$.). These prints may reproduce illustrations of various subjects : Geography, topography, landscape, historical monuments, aerial photographs, town-plans, architectural drawings, etc. The same prints may be employed in many divisions of the grid; in which case colour can be used to illustrate the precise question of circulation, zoning, etc...

The photographic reduction of all material is favoured as producing a unity in the entire demonstration. The colouring should be executed in waterproof inks. If poster colour is used, it should be fixed.

The essential texts should be both in English and French,

The Diagram of Display will allow the rapid reading of a planning project with reference to function or to classification, thus lending itself to all forms of analysis and commentary (public opinion, public authority, specialists, sociologists, economists, technicians, etc...) 


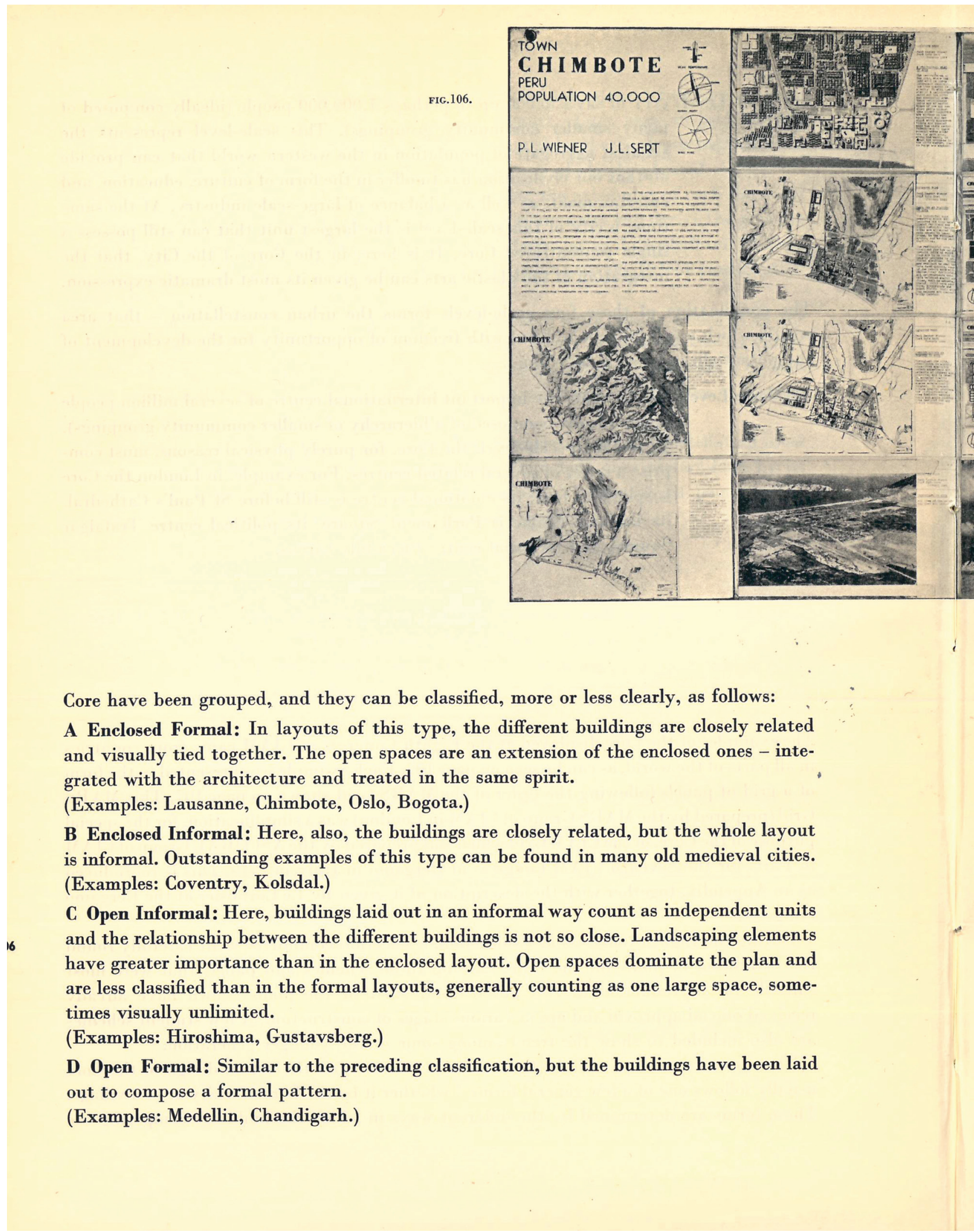

Figure 6. The MARS Grid, used for the presentation of projects at the CIAM 8 in Hoddesdon (UK). Very simplified, this grid includes only six columns, with each column divided into four fields. At the top, as an example, the town plan for Chimbote in Peru (P.L. Wiener and J.L. Sert). 
and theories through a series of books. ${ }^{33}$ With the CIAM Grid, and for the first time, Le Corbusier proposed a rigorous codification tool for future publications, which reflected the collection of individual tables that formed the different Grids. The format chosen for the individual boards ( $21 \times 33 \mathrm{~cm}-81 / 4 \times 13 \mathrm{in}$.) made it possible to quickly publish a single town plan by simply printing these boards with a spiral binding, ${ }^{34}$ or to build anthologies of projects based on geographical selection, programmatic groupings, or even according to the Grid division, into columns ("themes") and rows ("functions"). During the conference's preparatory period, the Commission chaired by Le Corbusier proposed to produce four books on "the functions" and twelve on "the themes," by simply collecting all the tables belonging to the same class to be exhibited in Bergamo.

Also, in this case, the ambitions linked to the Grid were completely unfilled. Subcommittee $1 \mathrm{C}$, whose aim was to study a publication plan according to the recommendation of President Sert, agreed that "it would be very useful to have books edited." ${ }^{35}$ It also concluded that it was necessary to completely abandon the Grid as a publication format, and limit the explanation of the projects with "a maximum of 12 documents ordered according to a simple sequence of urban scales." ${ }^{36}$ The excessive rigidity and systematic nature of the Grid and its tables were presumably criticized, based on the Commission's conclusions that stated: "The whole structure should not be rigid and tiring but, on the contrary, should be simple, easy, varied and lively." ${ }^{37}$

Unfortunately, unlike the previous conferences, no book was published on the results of the Bergamo Congress even though the "Actes officiels du 7ème Congrès CIAM" were released in Metron magazine by Bruno Zevi, ${ }^{38}$ who dedicated the cover of issue no. 33-34 to a beautiful photograph of Piazza Vecchia in Bergamo, which included the Palazzo della Ragione where the congress was held. Some traces of the conference are also present in Sigfried Giedion's book A Decade of New Architecture 1937-1947 (1951), which was created to divulge the results of Bridgwater's CIAM 6 (1947) ${ }^{39}$ but also included a fairly detailed account of the debates and preparatory work for CIAM 7.

Although Giedion reports extensively on the elaboration process of the CIAM Grid, he does not address any of the results of the debates on the town plans presented in Bergamo; he only publishes some of them in the final anthology. ${ }^{40}$ Furthermore, The Heart of the City (1952), ${ }^{41}$ dedicated for the publishing of the 1951 Hoddesdon's CIAM 8 results, included, in Part Two, some projects presented in Bergamo as part of an anthology of exemplary projects, ${ }^{42}$ and in Part Four, with the title Appendix, the presentation text of the CIAM Grid read by Le Corbusier in Bergamo, with some modifications and some abridged passages. ${ }^{43}$

Faced with these limited and disappointing results, many scholars shared their views claiming that CIAM 7's failure should be contrasted with CIAM 8's success. Its main merit, they argued, was that it served 
as preparation and maturation process of a more specific and innovative theme - the "Heart of the City" - which paved the way towards a more open town planning, one that is more attentive to social, anthropological, and political issues. Born under the premise of being the "Grid Congress," CIAM 7 is remembered today not only as "the anti-grid Congress," as Annie Pedret demonstrated well, ${ }^{44}$ but also as a well-organized event by the CIAM's Italian group, and, in particular, by local managers, ${ }^{45}$ who had prepared a rich program of recreational activities (Fig. 7). Although much appreciated by the participants, ${ }^{46}$ this program was criticized at the end of the conference by Enrico Peressutti, who denounced the risk that CIAM "would lose its working character of work and become only an international meeting of architects." 47
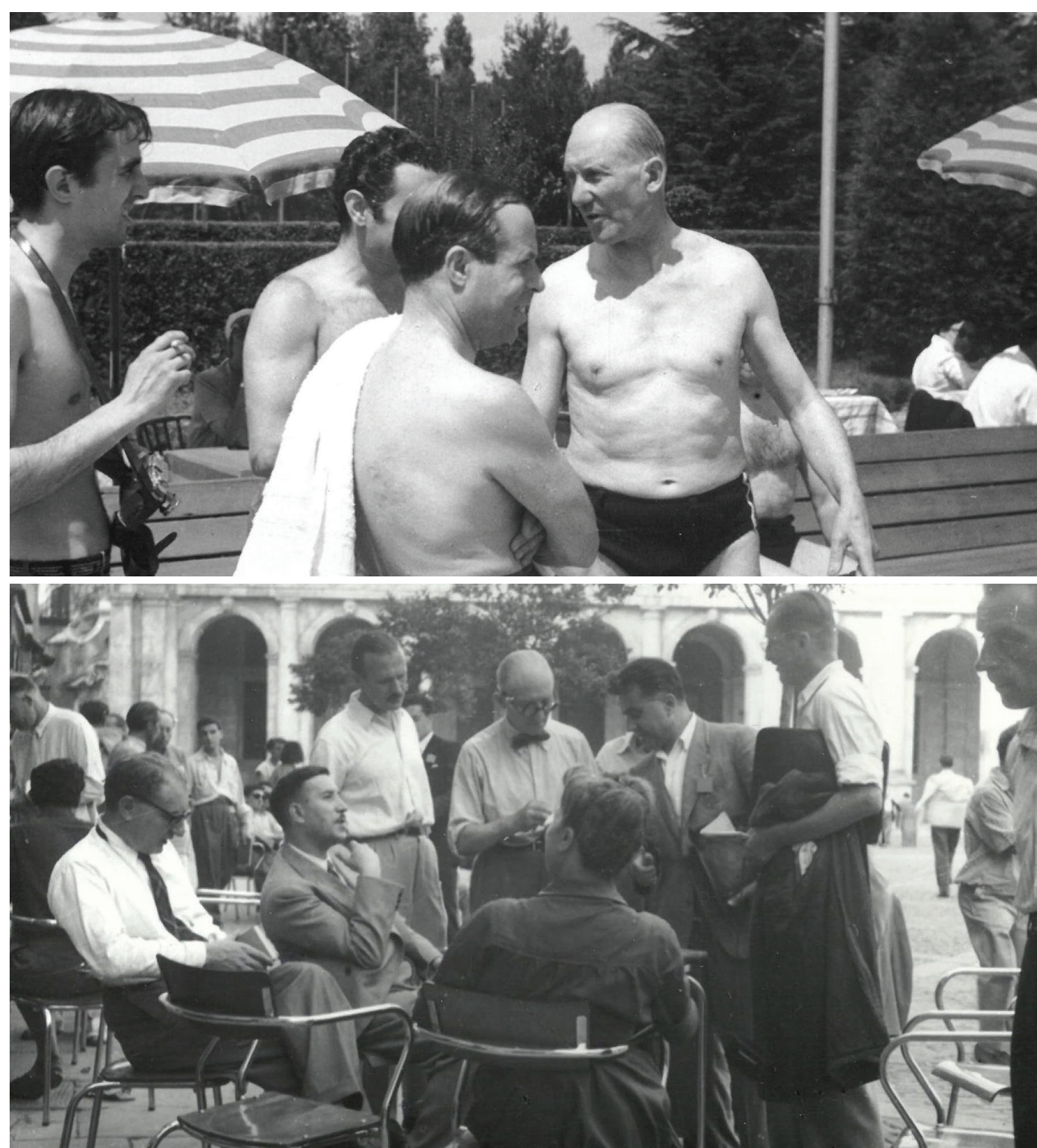

Figure 7. For the CIAM 7 a rich program of recreational activities had been organized. (a) Le Corbusier and Sert at the swimming pool of Dalmine (July 25); (b) a break in Piazza Vecchia, Bergamo, the last day of the congress (July 30 ), with Le Corbusier and Piero Bottoni in conversation with Eugène Claudius-Petit. 


\section{FOR A NEW INTERPRETATION OF THE CIAM GRID}

Based on Le Corbusier's statement that the Grid was a "tool for thinking," 48 Annie Pedret correctly interprets the fact that "the grid functioned both as an ideological tool for the functional city and as a way of structuring knowledge and reality," 49 further specifying that the Grid was "an epistemological structure that would guide thinking towards implementing the functional city as theorized in the Athens Charter." ${ }^{50}$ According to this interpretation, due to the close link between the dogmatic thought of the Athens Charter and the "epistemological structure" of the Grid, the criticism of functionalist urbanism by many CIAM members, particularly the younger ones, had logically led them to abandon this Grid, considered too rigid and dogmatic, and to replace it with new simplified versions. First with the "MARS Grid" presented at CIAM 8 in Hoddesdon, as already mentioned, then with the even more radical "Urban Re-Identification Grid," proposed by Alison and Peter Smithson at CIAM 9 in Aix-en Provence (1953), which replaced the functions of the Athens Charter with the more generic categories of "house," "street," "district," "city," and "relationship." 51 Consequently, following a rigorous historiographical reconstruction, the failure of the CIAM Grid must be read in relation to the emergence of the "young generation" in the post-war period and their cultural battles that led to the formation of "Team 10" and the dissolution of the CIAM in 1959.

However, if we carefully reread the words used by Le Corbusier in his opening speech at the CIAM in Bergamo, we can discover some clues of a more complex and more refined thought, which questions the canonical interpretation of a "rigid and dogmatic" Grid. In a first passage, Le Corbusier declared that the Grid "let think about town planning problems ... [and that it] ... does not pretend to make fine town planning schemes of itself." 52 With these affirmations, Le Corbusier suggests that the Grid's epistemological role is more to ask questions than to offer answers. In some ways, this thought recalls the words that Le Corbusier had already used in 1925 to warn his audience against any overly literal interpretation of the drawings of his famous "Plan Voisin": "The 'Voisin Plan' does not claim to provide the exact solution to the case of the centre of Paris. But it can serve to raise the discussion to a level appropriate to the times and to put the problem on a healthy scale." ${ }^{53}$ Just as the radical proposal of the "Plan Voisin" could be interpreted more as a tool to "read" the urban planning problems of Paris than as a "model" of an intervention to be implemented, we could then interpret the CIAM Grid as a tool that allows us to highlight the urban planning problems, rather than offering solutions with plans and projects.

In another passage, Le Corbusier says: 'Your 'interlocutors,' mute, are immediately before you." ${ }^{54}$ What does he mean by this quite enigmatic phrase? In the appendix publication of the book The Heart of the City, Le Corbusier modifies this sentence, which becomes simpler and clearer: 
"Your 'silent problems' immediately appear manifest before the eyes." ${ }^{5}$ In two other passages of the same speech, Le Corbusier once again uses the word "interlocutor," which becomes "problem" in the version published in the 1952 book. ${ }^{56}$ This insistence on using the word "interlocutor" does not therefore denote an inaccuracy of language, but a refinement of thought that Le Corbusier himself considered perhaps exaggerated and too cryptic, forcing to simplify the version printed in the CIAM "official" book, with the replacement of the word "interlocutor" with "problem."

With this rereading of the specific words used by Le Corbusier, however, we do not want to reach the conclusion that his original conception of the CIAM Grid was different from what facts and documents show: almost certainly Le Corbusier had conceived the Grid not only as a normative and dogmatic instrument but also as an instrument of power within the CIAM whose full ideological control he wanted to continue to guarantee. Regardless of the question of knowing what Le Corbusier's "true thought" might have been, we are interested, with a certain interpretative forcing, in considering this surprising appearance of the word "interlocutor" as if Le Corbusier had "accidentally" used it, as if it were a "Freudian slip." From the sequence of quotations discussed above emerges the fascinating hypothesis that the Grid itself could be interpreted as an "interlocutor": an interlocutor who speaks to us about problems to which "we are obliged to answer," but also a "silent" interlocutor, because they are the images that speak to us and with which we must have a dialogue. ${ }^{57}$

Starting from the question of the critical legacy of the CIAM Grid, we propose seventy years later to go beyond the failure of CIAM 7 and to start again from this vision of a Grid as an "interlocutor," as a character who "takes part in a conversation, a dialogue, a discussion." ${ }^{58}$ At the invitation of the Order of Architects of Bergamo who had planned a series of celebratory events for the CIAM of 1949, we have elaborated with a working group of the Politecnico in Milan ${ }^{59}$ a "new Grid" conceived no longer as an instrument of dogmatic and normative thought, but as an instrument of dialogical criticism. ${ }^{60}$

Quite differently from the historical context of 1949, which gave priority to the reconstruction of destroyed cities and the construction of "new towns" in a phase of significant urban expansion, we decided to limit the scope of application to projects and interventions to modify the existing, according to the paradigm of the "second life" of buildings and urban spaces. ${ }^{61}$ Consequently, our Second Life Grid is no longer based on the intersection of themes and functions, but on a scale of five proportional values that measure the critical tension between the existing and the new intervention. No longer a rigid normative instrument, it is conceived as a critical evaluation tool that takes up in certain aspects the idea of "measurement" used by Le Corbusier in describing the CIAM Grid as an "attempt to give town planning a measuring instrument ... real 'metrology'!" ${ }^{2}$ While in the CIAM Grid only the first theme - le milieu - concerned the context ("natural conditions, geographic, and demographic data") while the other eight 
themes were declined to describe the new urban intervention in positivist terms, in the Second Life Grid the context is at the center of attention, because we apply a scale of values to four groups of questions (What? Who? How much? How?) that aim to measure the quality of the dialogical relationship between the context and the new intervention.

\section{DESCRIPTION OF THE SECOND LIFE GRID}

The Second Life Grid (Fig. 8) consists of four categories (the columns), which have been identified as those with the most potential in order to produce a critique of a building (or a project), and two are specified in sub-categories; as a measure of a change, each of them is declined in five levels of intensity (the rows), from a total conservation of what exists to its total transformation, so to consent to break down and analyze the building in relationship to the pre-existing in a reading as objective as possible. The first category answers to the "what" question, describing the program and function of the building. The second responds to "who," and is used to identify who makes the intervention possible, such as property or financing. The category about "how much" is split into two more specific descriptions of the absolute and relative dimensions, both volume and surface. Finally, "how" is the place where the design strategy is specified, summarized under the sub-categories of image, material, and structure.

The application of the Second Life Grid took place in the form of a call for projects, based on the dedicated website produced by the Ordine degli Architetti [Professional Association Chapter] of Bergamo. ${ }^{63}$ At the end of the call period, a group of projects was selected and their authors were invited to the final conference held October 25-26, 2019 at the Accademia Carrara in Bergamo. The conference was structured in seven sessions, each of which conceived as a dialogue between three to six architects, and based on a critical comparison of their projects. The event, therefore, did not take place in the form of a collection of individual lectures, but rather as a critical seminar to reflect together on common themes, recalling in a certain sense the CIAM working method. During the conference, the function of the Second Life Grid was positively tested and confirmed as a critical tool that allows the evaluation of both the choices and the design outcomes. Its function is to deconstruct the unity of the project and then reassemble it, analyzing the conditions of possibility of the project and their consequences according to the existing, including the social and economic conditions, the natural and the geographic, the anthropological, and the cultural. The Grid, therefore, explicitly describes the authors' acts and practices, and also the creative process as a way of interpretation.

To illustrate the critical and no longer ideological role of the Grid, we conclude with a dialogue between some examples, articulated on the three main categories. 


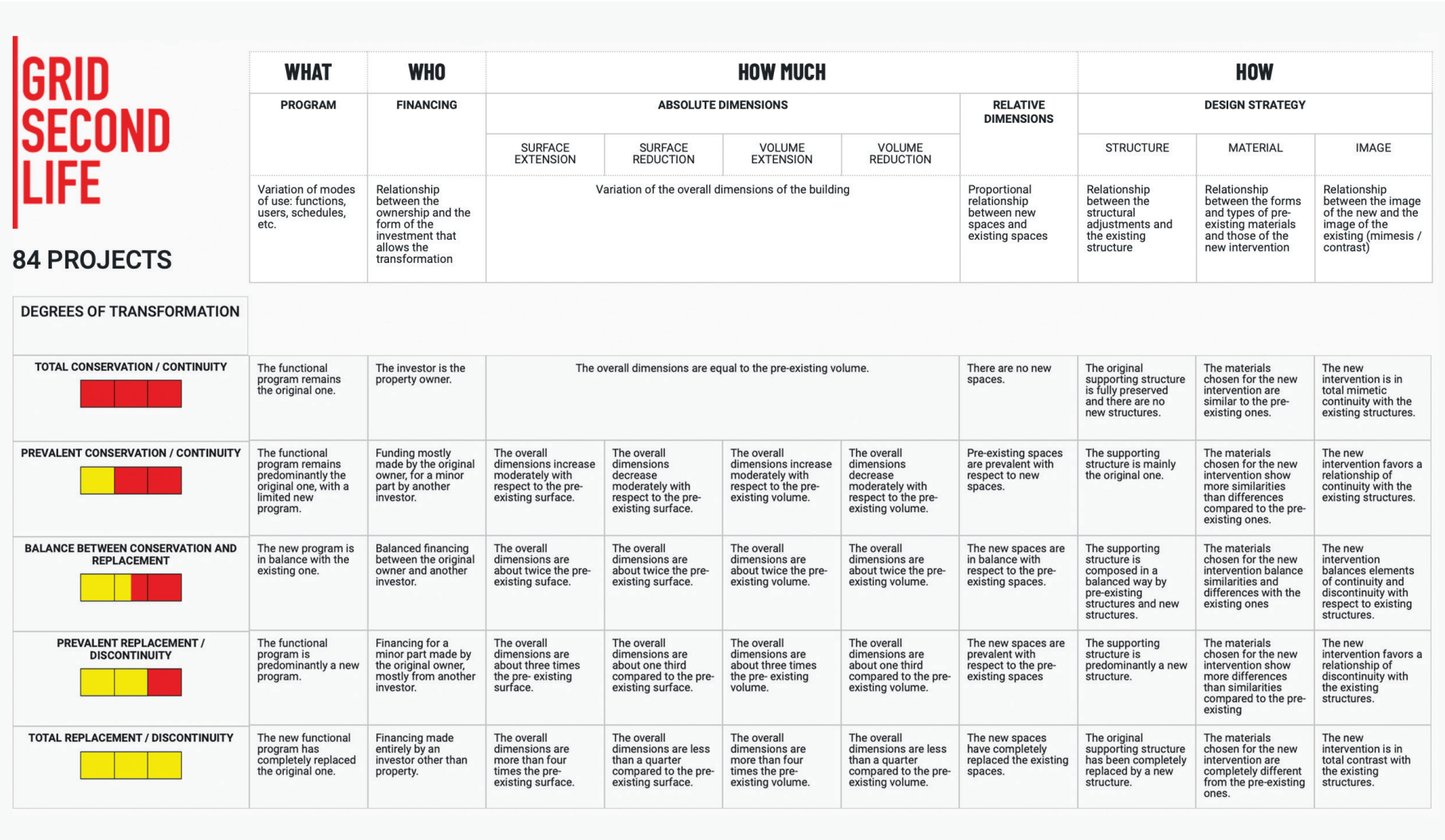

Figure 8. The Second Life Grid consists of four categories (the columns), two of which are specified in sub-categories; as a measure of change, each of them is defined by five levels of intensity (the rows), from the total conservation of what exists to its total transformation. The first category answers to the "what" question, describing the program and the function of the building; the second one responds to "who," and is used to identify who makes the intervention possible, such as property or financing; the category about "how much" is split in the two more specific descriptions of the "absolute" and "relative" dimensions, both "volume" and "surface," and "how" is the place where the design strategy is specified, under the sub-categories of "image," "material," and "structure."

\section{What?}

The first pair of projects (Fig. 9) is about the "what?" (program) category, illustrated using the project by Gianluca Frediani ("frediani+gasser architettura," Klagenfurt, Austria) for the Haus der Technik in Klagenfurt and Vincenzo Corvino's (Corvino and Multari, Naples, Italy) Covered Market Insula in Reggio Emilia: both are examples of a commercial building conversion in the context of a city center with a major issue being their permeability to the historical context. It is interesting to note how different the degrees of transformation assigned by the architects to the interpretation of their project are: a prevalent replacement of the program for Frediani, and a prevalence of conservation for Corvino. In fact, although Corvino partially maintains the original commercial function of the building, in both cases we are faced with an interesting intervention in which new functions and new connections give a new role to the architecture in the historical center of the town. 
The first project is a complete redevelopment of a shopping center as the new headquarters for the technical departments of the city of Klagenfurt (Carinthia, Austria). Located next to the St. Peter and Paul's Cathedral in the historic city center, the brutalist shopping center was built in the late 1970s to complete the reconstruction of the heavily bombed-out and almost completely destroyed urban block, in the form of a three-story massive body with a five-story tower above and two levels of underground parking. In answer to the programmatic changes, Frediani introduces a new hierarchy of spaces, with functional blocks and connecting zones that reproduce on a small scale an urban fabric with paths and public spaces. On an urban level, new perspectives are opened up throughout the whole building, to obtain views towards the Cathedral, together with public connections on the ground floor.

The second project is based on an architectural solution that describes the historical and permanent characters of the monument, converting it into a place for cultural and social identities. The project proposal is based on the intention to integrate into the building the functions of the new trade, optimizing the horizontal and vertical circulation, favoring the pedestrian connections and guaranteeing the welcoming, the reception, and the necessary and required accessibility of the entire complex. Even if the central open-air gallery maintains its original commercial function, the intervention increases the accesses and reorganizes the gallery-courts system, characterizing it in relation to their destinations and enhances its vocation to host other events, such as musical meetings, theatrical performances, or exhibitions, to keep the complex lively beyond the opening hours of the shops.

\section{How Much?}

The second pair of projects (Fig. 10) is about the "how much?" (relative dimensions) category, through the comparison between the project by Jabornegg-Pálffy Architects for Altenburg Abbey, and the renovation of the Machado de Castro National Museum by Gonçalo Byrne. A comparison is proposed on how the reuse of the volumes of the existing foundations and underground structures becomes, in terms of variation of relative dimensions, a significant part of the radical change of the historical building. If the first intervention is interpreted by its author as a balance between conservation and replacement, the second is described as a prevailing conservation project, although if it would be possible to reverse this interpretation if we look more closely at the real consistency of the transformation intervention.

In Joseph Munggenast's baroque design of Altenburg Abbey, the main façade was balanced by wide open spaces, which offered a pleasant view of the surrounding countryside and a good vantage point from which to observe the imposing volume of the abbey. Its structural foundation consisted of a raised embankment above part of the medieval abbey. 


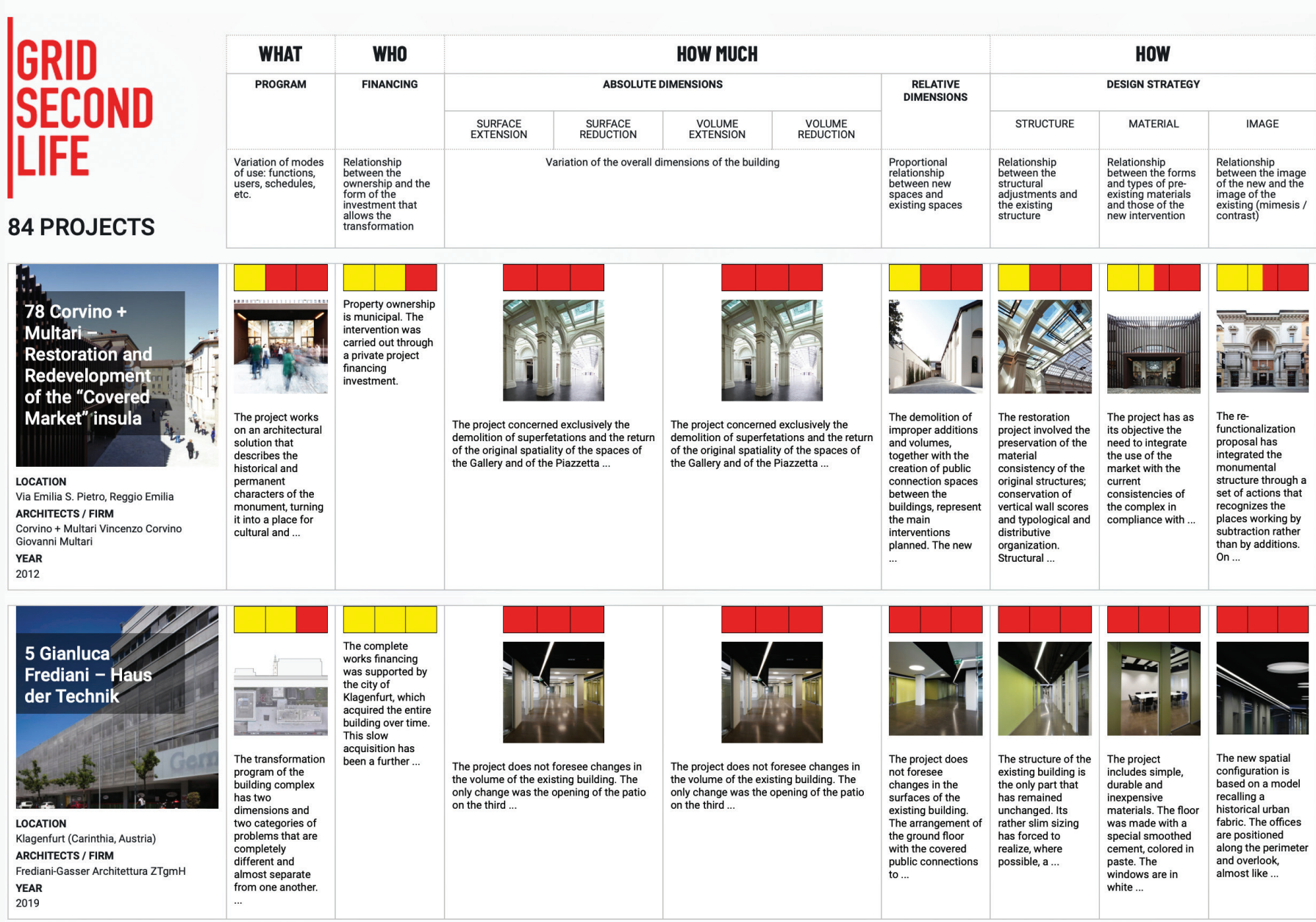

(b)
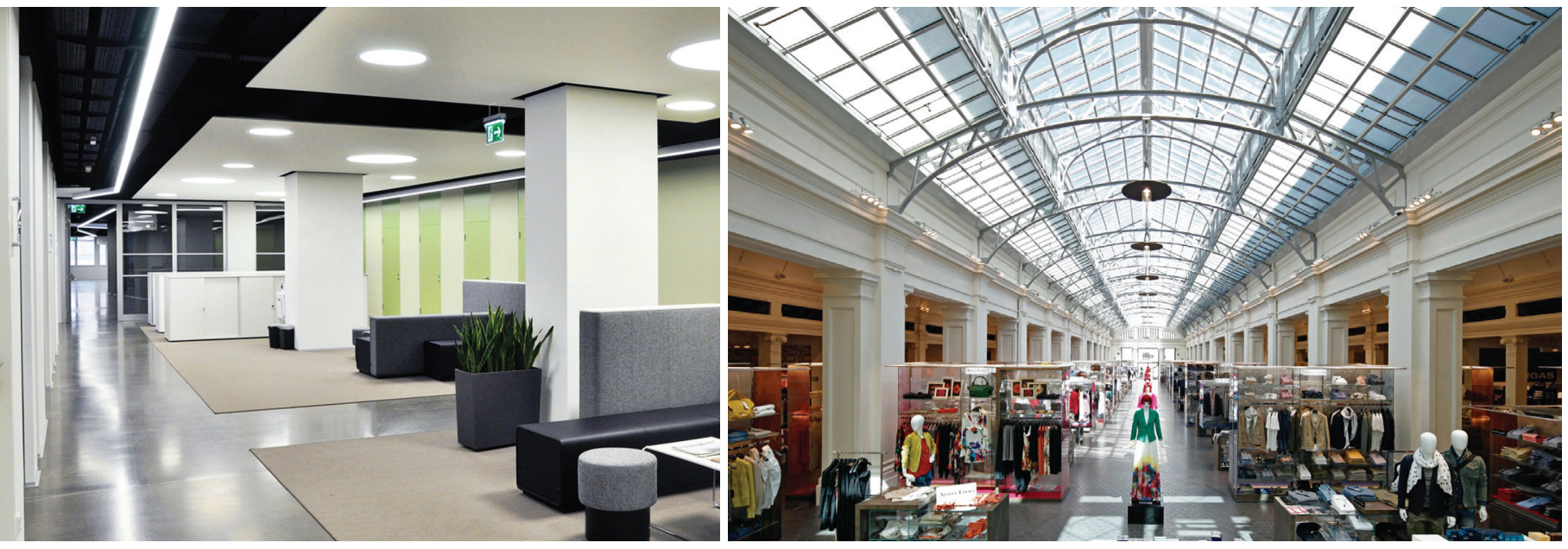

(c)

Figure 9. (a) Critical comparison between two examples of a renovation of a commercial building within the context of a city center: (b) "frediani+gasser architettura" (Klagenfurt, Austria), Haus der Technik, Klagenfurt (Austria), 2019 - the long corridor with the central spaces and the waiting areas; (c) Corvino + Multari (Naples, Italy), restoration and redevelopment of the "Covered Market" insula in Reggio Emilia (Italy), 2012 - the project includes the restoration of the Market Hall Gallery and the recovery of the former Chierici branch building and the former Student House, with the demolition of additional and improper volumes built through time, along with the creation of public spaces that connect the different buildings. 
In the 1990s, the weight of the embankment increasingly threatened the stability of the retaining walls. To relieve the pressure on existing structures and ensure the safety of the building, the embankment was excavated, and several layers of medieval remains came to light. To shelter the remains, a terrace was once again installed at the same level as the adjoining baroque courtyards, so that these medieval areas are now used as museum spaces forming a coherent extension of the exhibition areas already established in the main complex.

The Machado de Castro National Museum is located at the Alta de Coimbra (Portugal), whose history dates back to more than two thousand years. The core of this place of intense sedimentation and historical superimposition is the Roman cryptoporticus, built to contain the central forum at the end of the first century BC. The forum, placed as usual at the confluence of the cardo and decumanus as an administrative, political, and religious center was demolished at the time, but the cryptoporticus remained almost intact in its tectonics hosting, among other things, the Romanesque church of São João de Almedin (since the end of the twelfth century) and the loggia of Filippo Terzi. Due to the complex nature of the historical remains, and especially of the cryptoporticus, careful demolition and new construction work carried out to achieve a sustainable balance between the different systems of construction and to reduce their impact on this basis. New structures were designed not only to support new buildings but also to show the ruins of the old ones: Byrne's attempt was to link history by keeping all historical parts and character of the existing structures in place, hiding and minimizing the intervention on the historical structures. The lower volume adapts to the existing layout of the streets; the stone cladding is not mimetic but consistent with the solid matter of the surrounding buildings. The layout repeats the settlement solution with its morphology and hierarchy originally linked to the cryptoporticus of the Roman forum, which in turn is connected to the museum.

\section{How?}

The last pair of projects (Fig. 11) is about "how?" (the "material" as a design strategy) category, through a dialogue between a residential extension by Maria Giuseppina Grasso Cannizzo in Modica (Sicily, Italy), and the project for the Thalia Theatre in Lisbon by Gonçalo Byrne. These two examples show how existing materials can be used as the lexicon of the dialectical relationship between transformation and conservation. In both cases, a very sophisticated approach, based on an artificial memory of the existing materials, led to refined results. While Byrne interprets his intervention in terms of a balance between conservation and replacement of materials, for Grasso Cannizzo her building denotes a prevalent discontinuity. In her exemplary intervention, Grasso Cannizzo uses apparently contradictory strategies for the use of materials, such as conservation, demolition, or grafting, keeping in use consolidated spaces and functions 


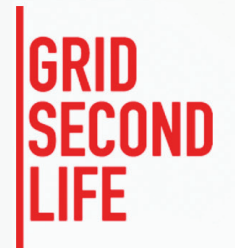

\section{PROJECTS}
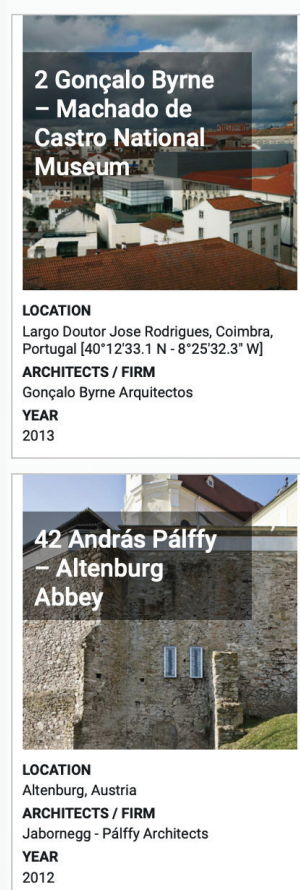

YEAR

\begin{tabular}{|c|c|}
\hline WHAT & WHO \\
\hline PROGRAM & FINANGING \\
\hline $\begin{array}{l}\text { Variation of modes } \\
\text { of use: functions, } \\
\text { users, schedules, } \\
\text { etc. }\end{array}$ & $\begin{array}{l}\text { Relationship } \\
\text { between the } \\
\text { ownership and the } \\
\text { form of the } \\
\text { investment that } \\
\text { allows the } \\
\text { transformation }\end{array}$ \\
\hline
\end{tabular}

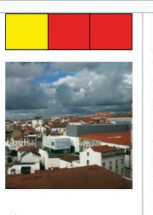

\section{The museum
stands in fact o} stands, in fact, on
an artificial plattorm by the
cryptoporticus,
built halfway through first century $\mathrm{BC}$, as the
podium of the podium of
Forum ...

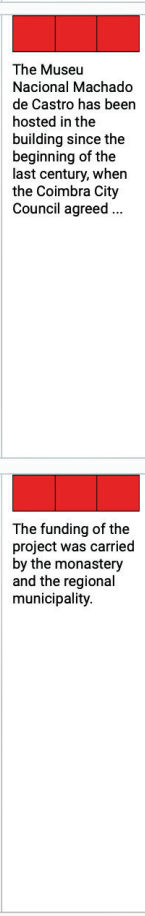

\section{The area oft he
archeological} archeologic
findings is converted into an
exhibition area. The
new exhibition new exhibition
surfaces connect surfaces connec
the existing puble areas
unit.
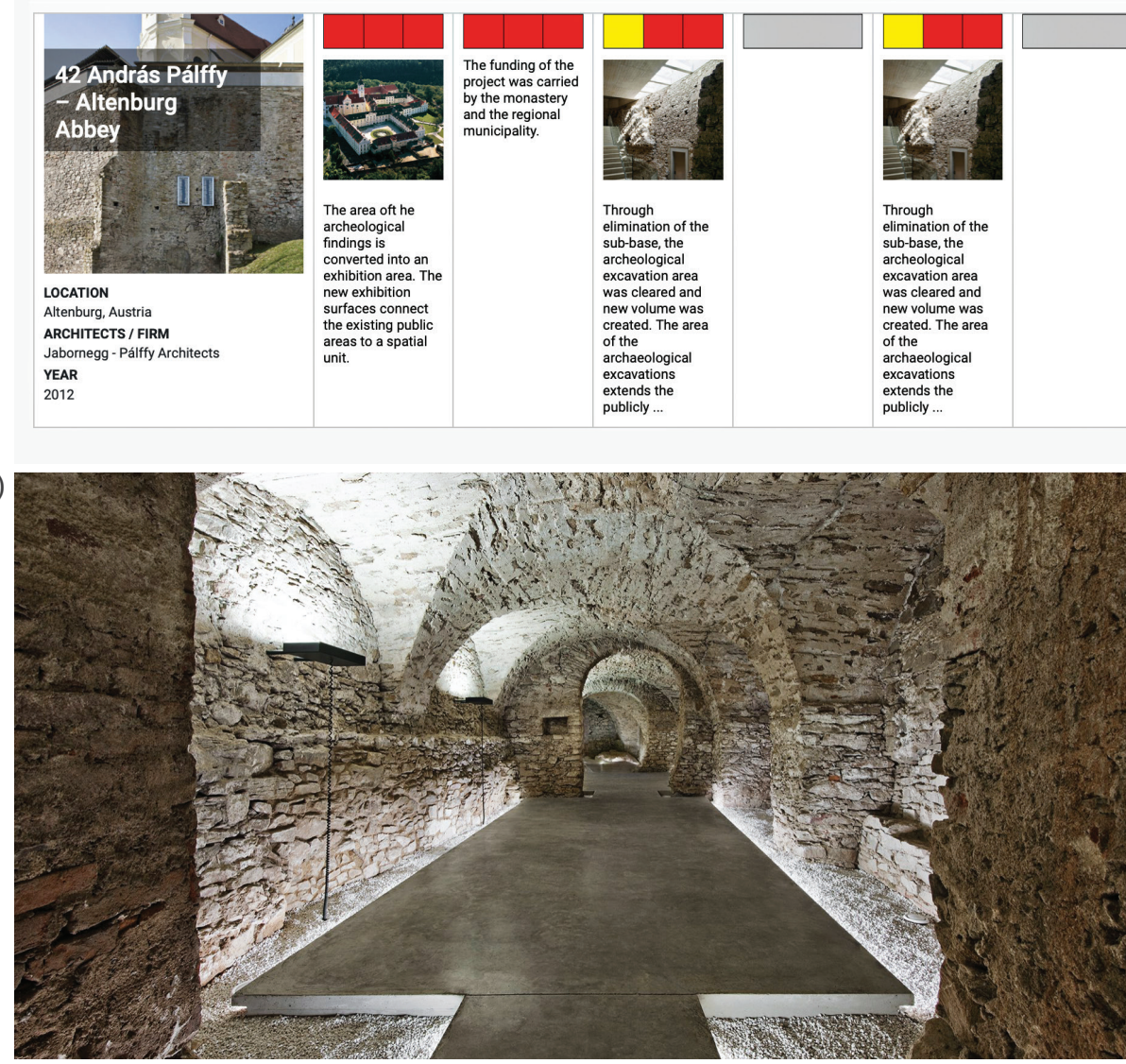
Through eliminination or
subbase the
aucheological
What excavation area was cleared and
new volume was
created. The area of the archaeologica
excavations excavation
extends the elimination of the
sub-base, the
archeological excavation area
was cleared and
nats Was cleared and
new volume was
created. The area archaeologí
excavations excavavitions
extends the
peblidy

(a)

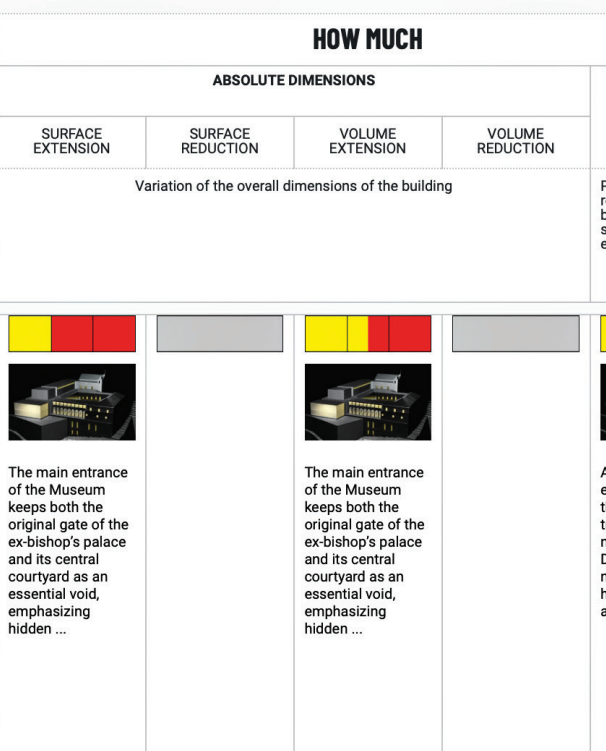

\begin{tabular}{|c|c|}
\hline \multirow[t]{2}{*}{$\begin{array}{l}\text { RELATIVE } \\
\text { DIMENSIONS }\end{array}$} & \\
\hline & STRUCTURE \\
\hline $\begin{array}{l}\text { Proportional } \\
\text { relationship } \\
\text { between new } \\
\text { spacess and } \\
\text { existing spaces }\end{array}$ & $\begin{array}{l}\text { Relationship } \\
\text { between the } \\
\text { structural } \\
\text { adjustuments and } \\
\text { the existing and } \\
\text { structure }\end{array}$ \\
\hline
\end{tabular}

HOW
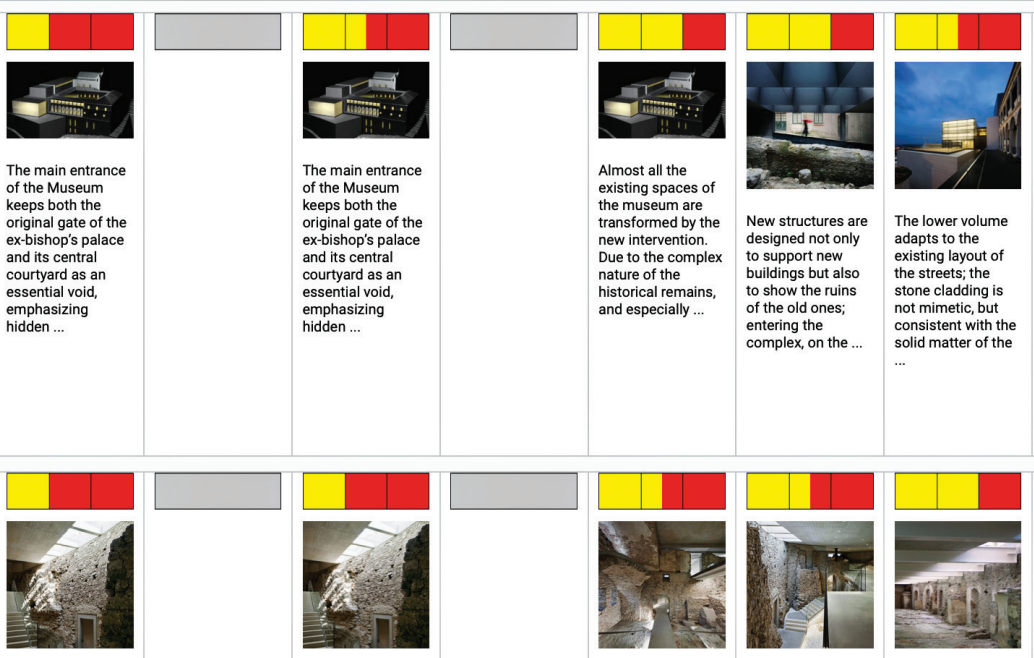

Almost all the
existing spaces of

the museum are
transformed by the

ew intervention Due to the complex nature of the historical remalis
and especially

to support new

buildings but also
to show the ruins

lo show the rulus
of the eld ones:
entering the entering the
complex, on the

The lower volume adapts to the
existing layout the streets; the
stone cladding is stone cladding is of container and
content is the matter of the
the project in order

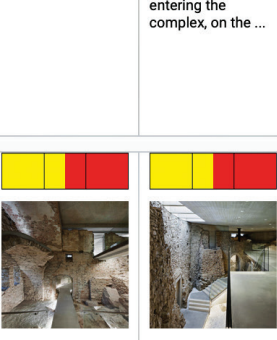

The intervention in the excavation are
offers a volume
extension of a bo extension of about
$30 \%$ in comparison to the public areas
actually in use.

Structural
interventions in the
existing area are existing area are
carried out by a (1) to correct the ...

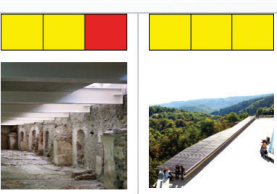

The materials The contrast of the

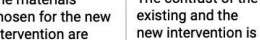
commonly different
from the existing $\begin{aligned} & \begin{array}{l}\text { readable in the } \\ \text { inside and the }\end{array} \\ & \text { int }\end{aligned}$ ones. exterior.

Figure 10. (a) Critical comparison between two examples of reuse of existing underground foundations and structures: (b) Jabornegg-Palffy Architects (Vienna), Altenburg Abbey (Austria), 2012 - through the elimination of the sub-base, the archeological excavation area was cleared and new volumes have been created (the area of the archaeological excavations extends the publicly accessible areas of the monastery); (c) Gonçalo Byrne Architects (Lisbon), restoration and extension of Machado de Castro National Museum in Coimbra (Portugal), 2013 - the core of this place of intense sedimentation and historical superimposition is the Roman cryptoporticus, a rectangular platform made by two vaulted layers that gives particular "Roman thermal" characteristics to the space. 
and, at the same time, activating new life cycles, and strengthening the relationships between the existing, the landscape, and the additions, evoking what has been lost. The realization returns the reflected image of changes and exploits the latent potential of the existing: every process of transformation originates from the existing body, used as a building material. The layout of the rooms, the details, the materials, the views of the surrounding countryside could satisfy, with appropriate expedients, the client's desire to meet new needs and to keep alive the memory of lost customs, but problems related to the poor execution have imposed a partial demolition. The reconstruction project did not want to correct the inconveniences, to eliminate defects, or to delete approximations, inconsistencies, and randomness, asking only to stratify on the existing without causing a change of scene. Since reinforced concrete is mainly used for plaster, both for internal and external visible surfaces, the architect decided to give a prevalent degree of transformation to the use of materials.

On the contrary, Byrne interprets his project in terms of a balance between conservation and replacement of materials, focusing on literary elements as wit, irony, and satire for the reconstruction of the ruins of a theatre dedicated to Thalia, the muse of satire. The need for a symbolic use of materials - the type of use that makes them literary materials - is clarified by the architect who appeals to Gottfried Semper: form is a question of representation, even of its symbolic nature. Thus, the first design scene of this representation was to recreate the scenery of the ruins, eliminating an incongruous three-story building overlooking the street: it was no longer a home theatre, and therefore the domestic mask was the first to disappear. Then, a limited palette of materials and techniques is the result of a series of studies that were made on the choice of colors, so that they could integrate with the context. In order to leave intact the ancient ruins inside with its sense of wonder, created by devastations and the passage of time, the exterior was covered with a terracotta concrete shell, forming a massive, monolithic body corresponding to the original volumes of the audience and the stage.

\section{CONCLUSIONS}

In conclusion, we can observe how the structure of the Grid does not claim to be exclusive nor unique. During the discussions provoked by its application, it immediately became evident that many possibilities of interpretation remain present, due to the fact that the architects themselves are the first to be encouraged to reflect on their own design choices. An initial result is to strengthen the concepts of modification, conservation, and their dialectics, trying to measure the value of adaptation (up to mimesis) or of contrast with the existing. Then, from a theoretical point of view, the Grid allows a description of the project as free as possible from any personal point of view, while imposing its flat two-dimensionality as a non-perspective description. 


\section{GRID SECOND LIFE}

\section{PROJECTS}

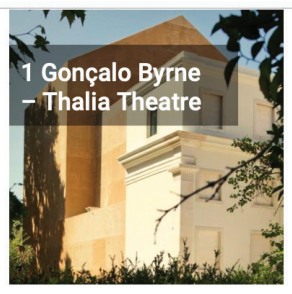

LOCATION

Lisbon, Portugal $38^{\circ} 44^{\prime} 41.4^{\prime \prime} \mathrm{N}-9^{\circ} 10^{\prime} 08.7$

ARCHITECTS / FIRM

Gonçalo Byme Arquitectos+Barbas Lopes YEAR

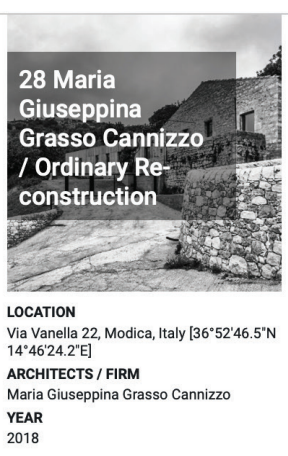

YEAR

\begin{tabular}{|c|c|}
\hline WHAT & WНО \\
\hline PROGRAM & FINANCING \\
\hline $\begin{array}{l}\text { Variation of modes } \\
\text { of use: functions, } \\
\text { users, schedules, } \\
\text { etc. }\end{array}$ & $\begin{array}{l}\text { Relationship } \\
\text { between the } \\
\text { ownership and the } \\
\text { form of the } \\
\text { investment that } \\
\text { allows the } \\
\text { transformation }\end{array}$ \\
\hline
\end{tabular}

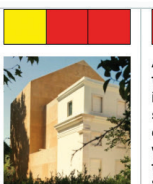

This small theatre,
built in front of the

residence of Count
Farrobo, and

named anter one of
nhe ninth Muses,

Jalia (in

Portuguese:

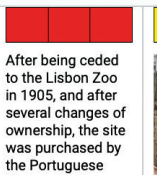

the Portuguese
State in 1948 ....

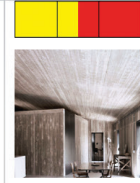

The client request:

reorganizing the
existing spaces to

obtain a house th
can meet the new

needs The goal

the project:
layout of .. (b)

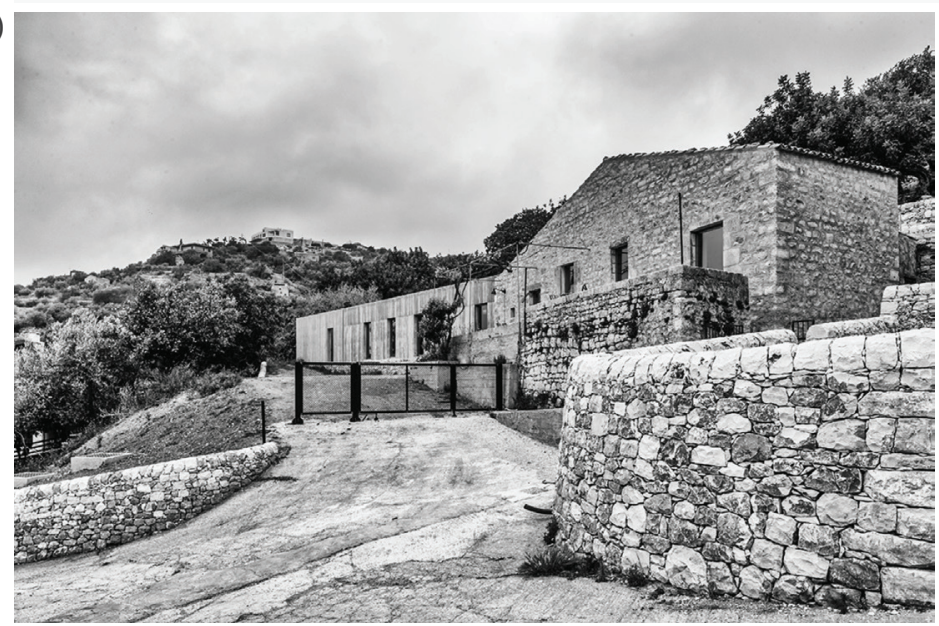

\begin{tabular}{|c|c|c|c|c|c|c|c|}
\hline \multicolumn{5}{|c|}{ HOW MUCH } & \multirow{2}{*}{\multicolumn{3}{|c|}{$\begin{array}{c}\text { HOW } \\
\text { DESIGN STRATEGY }\end{array}$}} \\
\hline \multicolumn{4}{|c|}{ ABSOLUTE DIMENSIONS } & \multirow{2}{*}{$\begin{array}{c}\text { RELATIVE } \\
\text { DIMENSIONS }\end{array}$} & & & \\
\hline $\begin{array}{l}\text { SURFACE } \\
\text { EXTENSION }\end{array}$ & $\begin{array}{l}\text { SURFACE } \\
\text { REDUCTION }\end{array}$ & $\begin{array}{l}\text { VOLUME } \\
\text { EXTENSION }\end{array}$ & $\begin{array}{l}\text { VOLUME } \\
\text { REDUCTION }\end{array}$ & & STRUCTURE & MATERIAL & IMAGE \\
\hline \multicolumn{4}{|c|}{ Variation of the overall dimensions of the building } & $\begin{array}{l}\text { Proportional } \\
\text { relationship } \\
\text { between new } \\
\text { spaces and } \\
\text { existing spaces }\end{array}$ & $\begin{array}{l}\text { Relationship } \\
\text { between the } \\
\text { structural } \\
\text { adjustments and } \\
\text { the existing } \\
\text { structure }\end{array}$ & $\begin{array}{l}\text { Relationship } \\
\text { between the forms } \\
\text { and types of ore } \\
\text { existing materials } \\
\text { and thoses of the } \\
\text { new intervention }\end{array}$ & $\begin{array}{l}\text { Relationship } \\
\text { between the inage } \\
\text { of the new and the } \\
\text { image of the } \\
\text { existing (mimesis / } \\
\text { contrast) }\end{array}$ \\
\hline
\end{tabular}
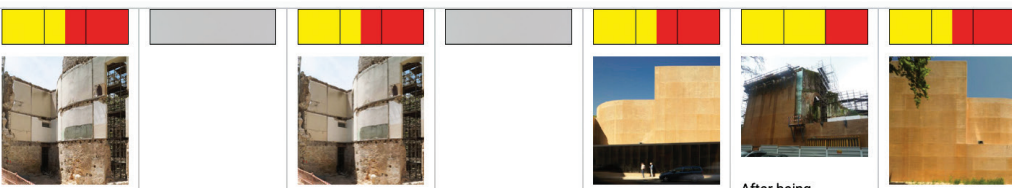

In 1840 the area
was scarcely was scarcely occupied by
palaces and

adjacent gardens
and farms. The new intervention, the face of the
impossibility of restoring .. the face of the
impossibility of restoring ...

$$
\begin{aligned}
& \text { The existing } \\
& \text { volumes are largely }
\end{aligned}
$$
volumes are largely
transformed by the transformed by the
intervention, which reveals the hidden
spatiality of the theatre. The new
structure at ground structure at
level is a...

After being
abandoned, the abandoned, the
remains of the remains of the
building became to
a slow a slow
consumption that one hundred and fifty years, a condition, a The exterior of the
box, the pure by cement treated with a chemical
finish, the final uniform
the ...

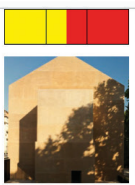

The project for the conversion of the
Thalia Theatre is a new urban complex balanced betwe
ancient and contemporary palette of materials
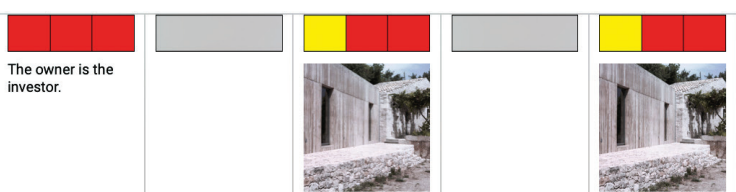

(a)
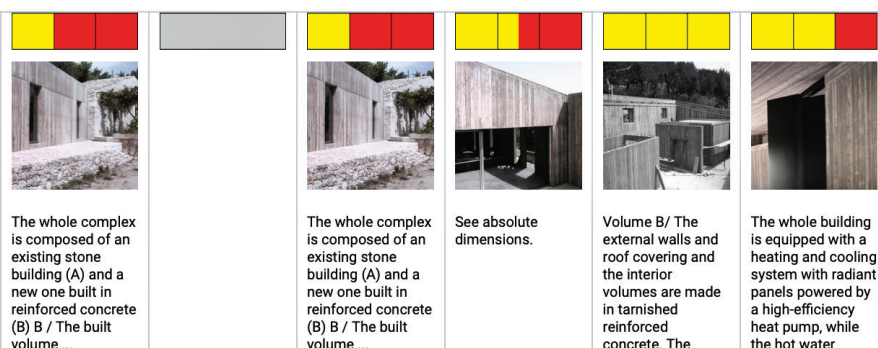
dimensions. existing stone
building (A) and nulding $(A)$ and a
new one built in reinforced concr

Volume $B /$ The external walls and
roof covering and roof covering and
the interior the interior
volumes are $m$ in tarnished
reinforced reinforced
concrete. The
decision to concrete. The
decision to have
both the inside The whole building
is equipped with a heating and cooling
system with radiain system with radian
panels powered by a high-efficiency
heat pump, while heat pump, wh
the hot water
supply supply...

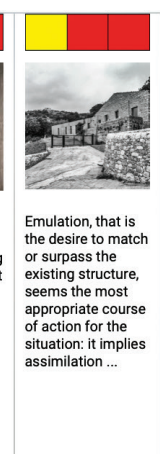

Figure 11. (a) Critical comparison between two examples of use of materials for creating a dialectical tension between conservation and transformation: (b) Maria Giuseppina Grasso Cannizzo (Vittoria, Italy), residential renovation in Modica (Italy), 2018 - the project implies assimilation of the model, interpretation and re-elaboration of the original, not a celebrated antique structure but an ordinary construction set in the space between the city and the countryside; (c) Gonçalo Byrne Architects with Barbas Lopes Arquitecto (Lisbon), restoration of Thalia Theatre in Lisbon (Portugal), 2012 - in order to leave untouched the old ruins in the interior with its sense of wonder, created by devastation and the passing of time, a shell of terracotta concrete forms a massive and monolithic body. 


\section{Notes}

1. Annie Pedret, Team 10: An Archival History (Abingdon, UK: Routledge, 2013), 58. The author writes: "The perception that CIAM 7 was the 'Grid Congress' is not surprising, given the nature of the published record." (note 54)

2. Paolo Nicoloso, "Il Ciam di Bergamo. Le Corbusier e le 'verità' discutibili della Carta d'Atene", in L'Italia di Le Corbusier, ed. Marida Talamona (Milan: Electa, 2012), 310. The essay by Paolo Nicoloso, rigorous and based on an accurate analysis of the numerous sources, represents the most complete critical description of the CIAM 7 in Bergamo, while for the discussion of Le Corbusier's role in the ideological guide of CIAM we refer to the pioneering essay by Giorgio Ciucci: Giorgio Ciucci, "CIAM. La poésie en casier", in Le Corbusier une encyclopédie, ed. Jacques Lucan (Paris: Centre Georges Pompidou, 1987), 88-92.

3. Eric Mumford, The CIAM Discourse on Urbanism, 1928-1960 (Cambridge MA, USA: The MIT Press, 2000).

4. Annie Pedret, "CIAM and the emergence of Team 10 thinking, 1945-59" (PhD diss., Massachusetts Institute of Technology, 2001); Annie Pedret, "Dismantling the CIAM Grid: New Values for Modern Architecture", in TEAM 10 1953-81: In Search of a Utopia of the Present, ed. Max Risselada and Dirk van den Heuvel (Rotterdam: NAi Publishers, 2005), 252-57; Annie Pedret, Team 10: An Archival History (Abingdon, UK: Routledge, 2013). 5. To arrive at these conclusions, the authors based their research on the comparison between different documentary sources, and in particular the unpublished document collections kept at the CIAM Archive, Giedion Collection, Roth Collection and Tyrwhitt Collection of the ETH/gta of Zurich, and the Sert Collection of GSD Harvard. The most comprehensive published compilation of CIAM 7 documents is CIAM 7 Documents, Bergamo, 1949 (Nendeln, Liechtenstein: Kraus Reprint, 1979), edited by Oswald Mathias Ungers and Liselotte Ungers, a reprint of the official reports elaborated during the congress, whereas many informations related to the real debate originate from important unpublished documents which were a "strictly confidential" collection of papers which circulated among members after CIAM 7. As described by Annie Perret, "many of these documents were not the versions circulated at the congress, but those edited by the chairmen of the commissions. The MARS Group version, "English Report of CIAM 7, 1949 at Bergamo, Italy", CIAM [Archive ETH/gta], 42-JT-4-1/88 is a collection of documents relating to CIAM 7 compiled by Jaqueline Tyrwhitt, including some reports presented to commissions that are not included in the published report for CIAM 7 of 1979" (Pedret, Team 10: An Archival History, 58.

6. "Bridgwater Commission IIIA. Urbanism: Preparation for CIAM 7," quoted from Sigfried Giedion, ed., A Decade of Contemporary Architecture (Zurich: Editions Girsberger, 1951), 25.

7. Giorgio Ciucci summed up very well the need to overcome the language barriers that had been created among the CIAM members, as the number of participating countries and therefore the languages used increased: no longer only French and German, then Italian and Spanish, but also English. He concludes that "the Grille Ascoral becomes the backbone of a common language." Giorgio Ciucci, "Le Corbusier, l'applicazione della Carta d'Atene, la Grille CIAM d'urbanisme, Chandigarh," in La Carta d'Atene. Manifesto e Frammento dell'Urbanistica Moderna, ed. Paola Di Biagi (Rome: Officina, 1998), 128.

8. The Preparatory Commission includes, under the direction of Le Corbusier, the doctor Pierre Winter, the mathematician François Le Lionnais, the Conservator of the Musée des Arts et Traditions Populaires Georges-Henri Rivière, lawyer Gaston Chereau, Ingénieur en Chef du Génie Rural Jean Dayre, and architects André Sive, Pierre Jeanneret, Roger Aujamme, André Bouxin, together with a group of young architects from ASCORAL including Georges Candilis. It met five times between October 9 and December 5, 1947, before the final approval on December 13, 1947 by the Conseil de Direction de l'ASCORAL. CIAM-ASCORAL, Programme du 7ème Congrès CIAM: Grille CIAM d'urbanisme. Mise en application de la Charte d'Athènes (Boulogne, Fr.: L'Architecture d'Aujourd'hui, 1948), 2. 9. Ibid.

10. On the cover of the publication is written that this Working Congress "will be held from $11^{\text {th }}$ to $19^{\text {th }}$ April1949; the place to be designated as circumstances permit." In the CIAM Council meeting in March 1948 in Paris the cities of Bergamo and Prague were proposed, 
but after the communist coup in February 1948 and the Soviet control over Prague, and after the elections in Italy in April 1948 and the triumph of the Christian Democratic Party, Bergamo was preferred, also because of the strong influence of the Italian CIAM Group. See Mumford, The CIAM Discourse, 182.

11. Eric Mumford quotes a letter sent by Giedion to Sert (May 6, 1949) two months before the CIAM meeting: "We haven't any idea what we can expect for examples of the CIAM Grilles for Bergamo." Mumford, The CIAM Discourse, 185.

12. The "distribution of tasks" in the publication gives a list of countries and projects, to be exhibited in Bergamo, and it is written: "Each group designated will do well to accept, in a spirit of friendly and necessary discipline, the role that is assigned to it, and not request its modification, except in a case of absolute necessity." CIAM, Programme du 7ème Congrès CIAM, 2.

13. "Yesterday arrived between 10:00 a.m. and 3:00 p.m., 28 grids that are here and that show that things have been understood." CIAM 7 Documents, 20.

14. Mumford, The CIAM Discourse, 187-88. Ibid., 321 (note 267): "List of CIAM 7 projects from CIAM [ETH/gta\} 42-JLS-12-8."

15. Archivio Nino Zucchelli, Dono Lina Zucchelli Valsecchi, 1999, GAMeC, Galleria d'Arte Moderna e Contemporanea di Bergamo. The architect from Bergamo Nino Zucchelli was the Secretary of the Organizing and Executive Committee of CIAM 7, while the architect Pino Pizzigoni was its President.

16. The city of Vienna is mentioned in the Report of the IV Commission (President Wells Coates) dedicated to the exam of the Grids from "the point of view of building technology" (CIAM 7 Documents, Bergamo, 81), and in a letter dated September 15, 1949 from the international transport company Jacky, Maeder \& Co. which was to send back to the owners a "box of architectural drawings" with the indication "Kosmos, Vienna" (Zucchelli Archives, section 1 fald. 10 fasc. 59). Another document (Archivio Zucchelli, sez. 1 fald. 10 fasc. 20) lists the "C.I.A.M. projects" existing in deposit in the big hall of Palazzo della Ragione, with some handwritten notes indicating that some boxes have already been returned, while three more names are mentioned: Helena Zyrkus, delegate of CIAM Poland (and author of the Warsaw Reconstruction Plan); Maroc (who could be represented by Marcel Ecochard, delegate of CIAM France but already active at that time in Rabat with the New Town of Sale-Rabat which will be presented at CIAM 8 in Hoddesdon); Le Bosquel, which was the exemplary project of Jean Bossu (delegate of CIAM France) for the reconstruction (1941-53) of a French village destroyed by the German army (see Xavier Dousson, "La reconstruction du village témoin du Bosquel dans la Somme après 1940. Récit, ambitions et paradoxes d'une opération singulière", In Situ, 21 (2013): 1-31, https://journals.openedition.org/ insitu/10470.

17. Drawings published in: Nestorio Sacchi, I Congressi Internazionali di Architettura Moderna: CIAM 1928-1959 (Milan: Consulta Regionale Lombarda degli Ordini degli Architetti, 1998), 67-68.

18. Some photographs preserved in the Zucchelli Archive also show the presence of drawings hanging directly on the perimeter walls of the hall. If we consider the fact that probably some projects had not used the CIAM Grid format in a complete way, on some panels more than one project may have been exposed, or some projects may have been exposed with single images, without using the CIAM Grid support.

19. See the right observation by Giorgio Ciucci: "Preparing the Grille Ascoral to present a plan also suggests designing the plan according to the principles of the Athens Charter". Giorgio Ciucci, "Le Corbusier, l'applicazione della Carta d'Atene, la Grille CIAM d'urbanisme, Chandigarh", in La Carta d'Atene. Manifesto e frammento dell'urbanistica moderna, ed. Paola Di Biagi (Rome: Officina, 1998), 129.

20. Pedret, Team 10: An Archival History, 58.

21. Report of the Commission $1 \mathrm{~A}$ (President Le Corbusier), CIAM 7 Documents, 36.

22. Among the harshest criticisms, that of Carl-Fredrik Ahlberg (1911-96), Swedish delegate of CIAM: "You can use a theory like a rigid box, in which you can put all the details of a plan in boxes, or you can look at the living city that you can't put in a box and try to make a plan of it. The use of grids is a similar problem." CIAM 7 Documents, 31.

23. CIAM 7 Documents, 20. Le Corbusier's opening speech will be printed in the Appendix of the book of CIAM 8 in Hoddesdon (Le Corbusier, "Description of the CIAM Grid, Bergamo 1949", in The Heart of the City: Towards the Humanisation of Urban Life, eds. Jaqueline Tyrwhitt, José Luis Sert, and Ernesto Nathan Rogers (London: Lund Humphries, 1952), 
171-76, with some variations, as highlighted in the following passage where Le Corbusier further criticizes "The Rebels": "Among the examples shown here there are, as always, a few from those rebels who like to advertise themselves by being different". Le Corbusier, "Description of the CIAM Grid", 172.

24. The Swiss delegate Arnold Hoechel criticizes the Grid and observes that "there are large holes in the grids and in some compartments." CIAM 7 Documents, 31.

25. The only image of a complete CIAM Grid is reproduced in the booklet CIAM, Programme du 7ème Congrès CIAM, 11-12, and represents Le Corbusier's Plan Grid for La RochellePallice, exhibited and discussed as a 1:1 scale test at the French Architecture and Urban Planning Exhibition in Vienna in May 1948. In the same publication of 1948, a "Report on the creation of the CIAM Grid" is published on the back cover, illustrated with a photograph of a Grid drawn by hand with white chalk on the long blackboard that Le Corbusier had installed on the wall of his studio in Rue de Sèvres in Paris. The Grids presented in Bergamo, or a reproduction of them, have not yet been found, although a letter from Enrico Peressutti to Nino Zucchelli dated December 20, 1949 (Archivio Zucchelli, sez. 1 fald. 10 fasc. 62), asking for information about the boxes containing the Grids, recalls that they should have been sent to the Institute of Microphotography of the Politecnico di Milano to be photographed, specifying that it was "extremely urgent to have them here because by 15 January 1950 the photographs of all of them must be taken and sent to their respective owners." Unfortunately, there are no documents that can prove the existence of this "Istituto di Microfotografia del Politecnico di Milano," and therefore of reproductions on microfilm of the CIAM Grids of Bergamo.

26. In vertical columns represent nine possible themes according to which it is possible to consider a project (from the environment to the ethical and aesthetical aspects), with the addition of a column for all the aspects not included in the first nine. To these ten columns are added the last two, which represent the "rational" or "subjective" reactions of users to a project. Horizontally, the rows represent the four functions of the Athens Charter (living, working, care of body and spirit, circulation), each characterized by a specific color, with the addition of a column for all the other functions.

27. Each box thus identifies a cross between one of the four functions and a specific aspect of the project or reactions to the project. Each table, $21 \times 33 \mathrm{~cm}(81 / 4 \times 13 \mathrm{in}$.) in size, had to be marked at the top right with a reference number that referred to the main theme and function, while a second colored mark, organized on four lines, made it possible to highlight the possible mix between different functions of the Athens Charter.

28. Le Corbusier, "Description of the CIAM Grid," 175.

29. Belgian delegate Paul Fitschy proposed to adopt "a grid of fixed height, but variable in length." CIAM 7 Documents, 31.

30. Ibid.

31. On the "MARS Grid" and on all subsequent versions of graphic or conceptual grids used in CIAM conferences, see Pedret, "Dismantling the CIAM Grid," 254-57. The column titles of the "MARS Grid" were: 1. The Region; 2. The Place; 3. The Core: Layout; 4. The Core: Expression; 5. The Core: Social Life; 6. The Core: Realisation.

32. For example, Column 2 is divided according to planning principles (2A. 3 dimensional plan [of area]; 2B. Land use; 2C. Communication; 2D. Photograph), while Column 5 proposes a division according to the different times of "social life" (5A. Daytime; 5B. Evenings; 5C. Sundays; 5D. Special Occasions).

33. CIAM 2 (1929): Die Wohnung für das Existenzminimum, 1930; CIAM 3 (1930): Rationelle Bebauungsweisen, 1931; CIAM 4 (1933): Le Corbusier, La Charte d'Athènes, 1943; CIAM 5 (1937): Logis et loisirs, 1937.

34. In his opening speech, Le Corbusier describes precisely the methods used for publication. CIAM 7 Documents, 22.

35. Commission for the "dissemination of the application of the Athens Charter since its creation through the publication of a volume of about 40 projects." CIAM 7 Documents, 32. 36. Progression from region, metropolitan area, city, to urban district, neighborhood unit, housing unit. CIAM 7 Documents, 44.

37. CIAM 7 Documents, 31.

38. CIAM, "Les Actes officiels du VIle CIAM," Metron 33-34 (1949): 49-72. These conference proceedings have certain parts absent from the full publication of the reprint CIAM 7

Documents (1979). In the previous issue of the magazine Metron, Bruno Zevi had published a long essay in the form of a "Message to the CIAM," in open controversy ("a splendid book, 
but a misleading one") with the positions defended by Sigfried Giedion in the book Space, Time and Architecture (1941). Zevi proposed an extension of the CIAM to architects coming from "organic" trends of the modern movement. Published in Italian, French, and English, the essay was sent by Zevi to all CIAM delegates for the opening of the conference, in the hope that it would become an object of debate. Bruno Zevi, "Della cultura architettonica: Messaggio al Congrès International d'Architecture Moderne," Metron 31-32 (1949): 6-30. 39. Giedion, A Decade of Contemporary Architecture (Zurich: Editions Girsberger, 1951). The final anthology of projects documents ten years of CIAM members' work between CIAM 5 in Paris (1937) and CIAM 6 in Bridgwater (1947), with the aim of demonstrating that despite the tragic interruption of the war the innovative work of the CIAM architects could continue.

40. Actually presented with a Grid in Bergamo and published by Giedion are the plans for Buenos Aires (Le Corbusier, Ferrari, Kurchan), London (MARS Group and Patrick Abercrombie), Harlow (F. Gibberd), Rio de Janeiro (Pedregulho housing, A.E. Reidy), Sotteville-les-Rouen (Marcel Lods), plus some plans indicated in the invitation of the ASCORAL booklet of 1948, but which had not participated in the exhibition in Bergamo, such as the Holiday Centre at Punta Balena, Uruguay (Antoni Bonet), and the Plan for the new Centre of Oulu (Alvar Aalto, 1943).

41. Tyrwhitt, Sert, and Rogers (eds.) The Heart of the City.

42. Village of Nagele (Merkelbach and De 8 Group), Plan for Pendrecht District in Rotterdam (Opbouw Group, presented by Bakema), Master Plan for Chimbote, Peru (Sert and Wiener), New Town Rabat Sale (Ecochard).

43. All the part concerning the use of the Grid for the publication of books (see note 34) is deleted from the 1952 book.

44. Pedret, Team 10: An Archival History, 58.

45. In particular Nino Zucchelli, secretary of the organizing committee, will be personally thanked by the CIAM Council (Cornelis van Eesteren, Ernesto N. Rogers) and the English CIAM group (Jane Drew, Wells Coates, Godfrey Samuel, Jaqueline Tyrwitt, Maxwell Fry, J. M. Richards), gathered in London to organize the next CIAM 8 of Hoddesdon, who sent him a postcard on August 31,1947 "remembering the beautiful stay in your lovely city and especially your friendships and collegiate care." (Archivio Zucchelli, sez. 1 fald. 10 fasc. 54). 46. Among the most appreciated recreational activities, a swim in the swimming pool of Dalmine (July 25), the screening of the film "Ladri di Biciclette" by Vittorio de Sica (July 26), the visit to Como of the exhibition dedicated to Giuseppe Terragni (July 26), the final reception with dance in San Pellegrino (July 30).

47. Declaration by Peressutti (with Albini, Bonet, Castelli, Gardella, Iriate, Wogensky, Candilis): "1. Members arrived at the Congress badly prepared. 2. The program of the Bergamo Congress was overloaded. 3 . The organizing group exaggerated the recreational side of the 7th Congress and the Council did not dose the proportion between work and leisure severely enough. We underline the danger for CIAM to lose its working character and to become only an international meeting of architects. 4 . In order to ensure the vitality of CIAM it is indispensable that the Council make use of new forces. 5. It is essential that between two Congresses the groups develop an action in the spirit of CIAM and remain in constant contact." CIAM 7 Documents, 102.

48. CIAM 7 Documents, 21.

49. Pedret, "Dismantling the CIAM Grid," 253.

50. Pedret, Team 10: An Archival History, 60.

51. Pedret, "Dismantling the CIAM Grid," 255.

52. CIAM 7 Documents, 20-21.

53. Le Corbusier, Urbanisme (Paris: Crès, 1925), trans. Frederick Etchells as The City of Tomorrow (London: J. Rodker, 1929), 174. See Bruno Reichlin, "L'Esprit de Paris", Casabella 531-532 (January-February 1987): 52-63.

54. CIAM 7 Documents, 21.

55. Le Corbusier, "Description of the CIAM Grid," 172.

56. The first sentence is: "Your 'interlocutor' [authors' emphasis] is there who says to you: 'Take care of these things; here is the question asked"' (CIAM 7 Documents, 21), which becomes in the 1952 book: 'Your 'problem' [authors' emphasis] lies before you and demands: 'Look at these points here. This is the position"' (Le Corbusier, "Description of the CIAM Grid", 174). The second sentence is: "The 'interlocutor' [authors' emphasis] is in front of you; 'he' [authors' emphasis] talks about the occupation of the territory, flat, on the 
ground: these are questions that you are obliged to answer" (CIAM 7 Documents, 21), which becomes: 'The 'problem' [authors' emphasis] lies exposed before us. The 'Grid' [authors' emphasis] tells of the LAND UTILISATION (two dimensional planning) on the ground, and we must reply to the questions posed here" (Le Corbusier, "Description of the CIAM Grid", 174).

57. Le Corbusier speaks of a "visual method" that "enables the eye to read the essential information quickly [...] Instead of reading one sees." Le Corbusier, "Description of the CIAM Grid", 174.

58. Merrian-Webster English online Dictionary: https://www.merriam-webster.com/dictionary/ interlocutor

59. Research agreement between the Ordine degli Architetti [Professional Association Chapter] of Bergamo (OAB) and the Department of Architecture and Urban Studies (DAStU) of the Politecnico di Milano, research coordinated by Pierre-Alain Croset, with Guya Bertelli, Andrea Canclini, Federico De Ambrosis, Andrea Gritti, Pasquale Mei, and with the collaboration of the student Matteo Ciccarelli.

60 . Hélène Jannière states that the condition of existence of the critic is "the contradictory debate, which differentiates it from the theories of architecture." Hélène Jannière, Critique et architecture. Un état des lieux contemporain (Paris: Éditions de la Villette, 2019), 23. 61 . With the same term of "second life" have been named all the initiatives coordinated by the OAB on the occasion of the seventieth anniversary of CIAM 7 (http://www. ciam2019.it/), in particular "Atlas Second Life" (http://www.aslarchitettura.it/, a repertoire of disused buildings and public spaces to be regenerated; "Grid Second Life" (https:// www).gridsecondlife.it/), the subject of this paper; "Forum Second Life" (http://www. forumsecondlife.it/), a 4-day conference (October 23-26, 2019) dedicated to the care for the people, the city and the landscape, based on five elements (norm, innovation, reuse, economy, and sociality).

62. Le Corbusier, "Description of the CIAM Grid," 174.

63. At this call answered eighty-four groups of architects, uploading a project on the web platform www.gridsecondlife.it, mostly from Europe, with some participation from China and Latin America.

\section{Acknowledgments}

We are particularly thankful to the reviewers of this article for their stimulating comments. We also thank our colleagues Federico De Ambrosis, Paolo Scrivano, and Luka Skansi for their comments on a previous version of this paper, together with Aya Jazaierly for the final revision of the manuscript. We are also grateful to the Ordine degli Architetti [Professional Association Chapter] of Bergamo and to its President Gianpaolo Gritti for having invited us to participate in the program of celebrations for the $70^{\text {th }}$ anniversary of the CIAM of Bergamo and for having contributed financially to this research. 


\section{Credits}

Figures 1 and 5: through the courtesy of ( $)$ Archivio Piero Bottoni, Dipartimento di Architettura e Studi Urbani (DAStU), Politecnico di Milano.

Figures 2, 3, 7: through the courtesy of ( Archivio Nino Zucchelli, Dono Lina Zucchelli Valsecchi, GAMeC, Galleria d'Arte Moderna e Contemporanea di Bergamo.

Figure 4: retrieved from L'lllustrazione Italiana 31 (July 31,1948), and Metron 31-32 (1948). Figure 6: retrieved from Jaqueline Tyrwhitt, José Luis Sert, and Ernesto Nathan Rogers (eds.), The Heart of the City: Towards the Humanisation of Urban Life (London: Lund Humphries, 1952), 106-07.

Figure 8: provided by the Authors.

Figure 9: (a): provided by the Authors; (b) image by Gerhard Maurer (Klagenfurt, Austria) through the courtesy of (c) "frediani+gasser architettura" (Klagenfurt, Austria);

(c) through the courtesy of (C) Corvino + Multari (Napoli, Italy).

Figure 10: (a): provided by the Authors; (b) through the courtesy of $\odot$ Jabornegg-Palffy Architects (Vienna, Austria); (c) through the courtesy of () Gonçalo Byrne Architects (Lisbon, Portugal).

Figure 11: (a): provided by the Authors; (b) through the courtesy of () Maria Giuseppina Grasso Cannizzo (Vittoria, Italy); (c) @ through the courtesy of Gonçalo Byrne Architects with Barbas Lopes Arquitecto (Lisbon, Portugal).

Pierre-Alain Croset is a Professor of Architecture at the Department of Architecture and Urban Studies, at the Politecnico in Milan. After graduating from the EPFL in Lausanne (Switzerland), he worked as Associate Editor for Casabella from 1982 to 1996 under the editorship of Vittorio Gregotti. From 1985 to 1993 he collaborated with Swiss architect Luigi Snozzi, and from 1995 he has run his practice in Brescia (Italy) with his wife Chiara Rovetta. He taught at the Technical University of Graz (1997-2002), serving also as Dean of the Faculty of Architecture (2001-02). From 2002 to 2015, he taught at the Politecnico in Turin, where he served also as Director of the College of Architecture. From 2015 to 2018, he was a Professor of Architecture and Architecture Department Head at Xi'an Jiaotong-Liverpool University in Suzhou, China. E-mail: pierre.croset@polimi.it

Andrea Canclini is an Adjunct Professor of Theory in Contemporary Architectural Design at the Politecnico in Milan, and a Visiting Professor at Beirut Arab University. He graduated in Architecture (Politecnico di Milano, 1996) and in Philosophy (Università degli Studi di Perugia, 2012), and holds a PhD in Architecture (Politecnico di Torino, 2017). As a researcher, he has participated in international conferences and published worldwide on architectural critic and history, and their cultural basis. E-mail: andrea.canclini@polimi.it 